\title{
Reward Devaluation Attenuates Cue-Evoked Sucrose Seeking and Is Associated with the Elimination of Excitability Differences between Ensemble and Non-ensemble Neurons in the Nucleus Accumbens
}

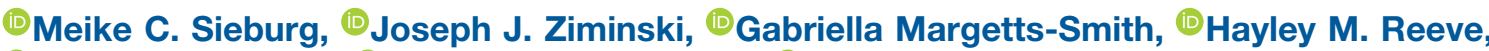 \\ (ㄴ)Leonie S. Brebner, 난 Hans S. Crombag, and ${ }^{-}$Eisuke Koya
}

https://doi.org/10.1523/ENEURO.0338-19.2019

Sussex Neuroscience, School of Psychology, University of Sussex, Falmer BN1 9QG, United Kingdom

\section{Visual Abstract}

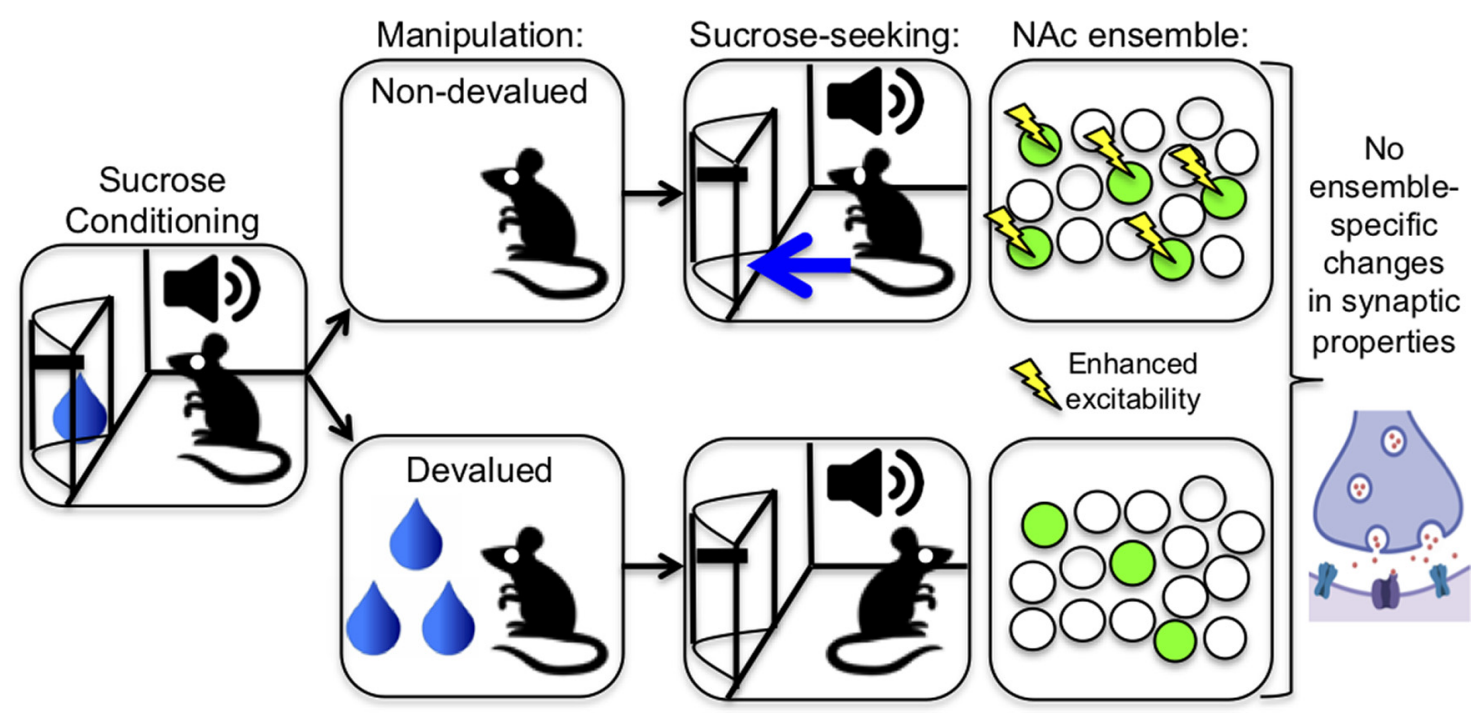

Animals must learn relationships between foods and the environmental cues that predict their availability for survival. Such cue-food associations are encoded in sparse sets of neurons or "neuronal ensembles" in the nucleus accumbens (NAc). For these ensemble-encoded, cue-controlled appetitive responses to remain adaptive, they must allow for their dynamic updating depending on acute changes in internal states such as physiological hunger or the perceived desirability of food. However, how these neuronal ensembles are recruited and physiologically modified following the update of such learned associations is unclear. To investigate this, we examined the effects of devaluation on ensemble plasticity at the levels of recruitment, intrinsic excitability, and synaptic physiology in sucrose-conditioned Fos-GFP mice that express green fluorescent protein (GFP) in recently activated neurons. Neuronal ensemble activation patterns and their physiology were examined using immunohistochemistry and slice electrophysiology, respectively. Reward-specific devaluation following $4 \mathrm{~d}$ of ad libitum sucrose consumption, but not general caloric devaluation, attenuated cue-evoked sucrose seeking. This suggests that changes in the hedonic and/or incentive value of sucrose, and not caloric need, drove this behavior. Moreover, devaluation attenuated the size of the neuronal ensemble recruited by the cue in the NAc shell. Finally, it eliminated the relative enhanced excitability of ensemble $\left(\mathrm{GFP}^{+}\right)$neurons against non-ensemble $\left(\mathrm{GFP}^{-}\right)$neurons 
observed under non-devalued conditions, and did not induce any ensemble-specific changes in excitatory synaptic physiology. Our findings provide new insights into neuronal ensemble mechanisms that underlie the changes in the incentive and/or hedonic impact of cues that support adaptive food seeking.

Key words: intrinsic excitability; neuronal ensembles; nucleus accumbens; reward devaluation; synaptic physiology

\section{Significance Statement}

Learned associations between food and the cues that predict their availability are encoded in neuronal ensembles in reward-relevant brain areas, such as the nucleus accumbens. Such learning is often accompanied by synaptic and intrinsic plasticity within these ensemble neurons. However, it is unclear how these plasticity changes manifest specifically in cue-activated neurons in response to decreases in reward value [e.g., following reward-specific or general (caloric) devaluation]. We reveal that shifts in excitability, but not excitatory, synaptic physiology between ensemble and non-ensemble neurons in the nucleus accumbens shell coincide with reward-specific devaluation. Our findings provide new insights into how changes in the perceived properties of food reward update cue-food associations by potentially fine-tuning neuronal excitability.

\section{Introduction}

Animals and humans form associations between environmental cues and the foods whose availability they predict (Petrovich, 2013; Jansen et al., 2016). Such cues obtain motivational significance following Pavlovian conditioning and exert powerful control over food seeking (Day and Carelli, 2007; Petrovich, 2013). Critically, organisms have to adapt their appetitive behaviors and related physiological responses not only according to the changing external, but also internal environment. For instance, excessive consumption of a certain type of food can alter its current attractiveness via changes in homeostatic need or its incentive and/or hedonic properties to regulate cue responsivity (Holland and Rescorla, 1975; Goldstone et al., 2009; West and Carelli, 2016). The malfunctioning of

Received August 14, 2019; accepted October 23, 2019; First published November 7, 2019

The authors declare no competing financial interests.

Author contributions: M.C.S., J.J.Z., H.S.C., and E.K. designed research; M.C.S., J.J.Z., G.M.-S., H.M.R., and L.S.B. performed research; M.C.S., J.J.Z., and E.K. analyzed data; M.C.S., J.J.Z., G.M.-S., H.M.R., L.S.B., H.S.C., and E.K. wrote the paper.

This research was supported by the Biotechnology and Biological Sciences Research Council (BBSRC) Grant BB/M009017/1; and The University of Sussex Strategic Development Funds, Sussex Neuroscience 4 year PhD programme.

M.C. Sieburg's present address: Department of Biomedicine/DANDRITE, Aarhus University, 8000 Aarhus C, Denmark.

G. Margetts-Smith's present address: University of Exeter College of Medicine and Health, Hatherly Laboratories, Exeter EX4 4PS, United Kingdom.

Acknowledgments: We thank Yavin Shaham (National Institute on Drug Abuse Intramural Research Program, Baltimore, MD) for providing helpful advice regarding the devaluation experiments. The diagram of the synapse in the visual abstract was made using BioRender.

Correspondence should be addressed to Eisuke Koya at e.koya@sussex.ac.uk.

https://doi.org/10.1523/ENEURO.0338-19.2019

Copyright (C) 2019 Sieburg et al.

This is an open-access article distributed under the terms of the Creative Commons Attribution 4.0 International license, which permits unrestricted use, distribution and reproduction in any medium provided that the original work is properly attributed. such behavioral flexibility may lead to inappropriate responding to food cues and dysregulation of food intake (i.e., overeating) and contribute to excessive weight gain (Boswell and Kober, 2016; Jones et al., 2018; Kosheleff et al., 2018). These are pressing issues in today's society, in which we are surrounded by cues associated with unhealthy foods (e.g., junk food advertisements). Hence, elucidating the neurobiological processes underlying the updating of cue-food associations is crucial to obtain a better understanding of maladaptive eating behaviors.

It has been shown that associations between cues and rewarding substances such as food and drugs of abuse are dependent on sparsely distributed sets of neurons called neuronal ensembles (Pennartz et al., 1994; Carelli et al., 2000; Koya et al., 2009; Whitaker et al., 2016, 2017; Ziminski et al., 2017, 2018). These neurons can act as memory engrams to encode and store cue reward memory representations (Tonegawa et al., 2015; Whitaker and Hope, 2018). In addition to other mesocorticolimbic structures, these appetitive memory ensembles are found in the nucleus accumbens (NAc), a brain area well established to play a causal role in hedonic processing and incentive learning (Kelley, 2004; Day and Carelli, 2007; Castro et al., 2015; West and Carelli, 2016).

Importantly, intrinsic and synaptic plasticity modulate neuronal network function in the wider mesocorticolimbic network and plays a pivotal role in many forms of associative learning (Stuber et al., 2008; Kourrich et al., 2015; Whitaker et al., 2017). The former primarily involves changes in the electrical or excitability properties of the neuron that influence neuronal firing, while the latter involves changes in neuronal communication at the synapse (Kourrich et al., 2015). For instance, studies using Fos-GFP mice that express green fluorescent protein (GFP) in behaviorally activated neurons have shown that intrinsic and synaptic plasticity within NAc ensembles, particularly in the shell region, help to encode cue-reward associations (Barth, 2004; Whitaker et al., 2016; Ziminski et al., 2017). Recently, it was found that changes in ap- 
petitive associative strength following extinction learning restricted the ability of food cues to recruit a hyperexcitable neuronal ensemble in the NAc shell subregion (Ziminski et al., 2017). Also, studies have shown that NAc shell neurons activated by specific drug-cue associations exhibit remodeling of excitatory glutamatergic synapses (Koya et al., 2012; Whitaker et al., 2016). Together, physiological modifications in a select group of neurons are likely to establish highly specific appetitive associative memories.

Here, we examined how ensemble-specific changes in intrinsic and synaptic plasticity underlie updating of cuefood associations using a reward-specific devaluation procedure. This approach is widely used to assess behavioral flexibility following changes in the rewarding value of food (West and Carelli, 2016). To this end, we devalued sucrose reward using a reward-specific, sucrose satiation procedure and compared it with a nonreward specific satiation manipulation. Subsequently, we examined plasticity changes in behaviorally activated NAc shell neurons in sucrose-conditioned Fos-GFP mice at the levels of ensemble size, excitability, and synaptic physiology following reward-specific devaluation.

\section{Materials and Methods}

\section{Animals}

Male wild-type C57BL/6 mice were purchased from Charles River UK. Male heterozygous Fos-GFP mice (https://www.jax.org/strain/014135; RRID:IMSR_JAX:014135) on a C57BL/6 background that originated from the laboratory of Allison Barth (Carnegie Mellon University, Pittsburgh, PA) were obtained from the in-house breeding program at the University of Sussex. All mice were housed two to three per cage and maintained on a $12 \mathrm{~h}$ light/dark cycle (lights on at 7:00 A.M.) at a temperature of $21 \pm 1^{\circ} \mathrm{C}$ and $50 \pm 5 \%$ humidity, and had access to standard chow (BK001 E Rodent Breeder and Grower Diet, SDS) and ad libitum water. Unless noted, 1 week before and for the entire duration of the behavioral experiments, mice were food restricted to $90 \%$ of their free-feeding body weight (adjusted for age). Mice were 9-10 weeks old at the beginning of behavioral testing. Fos-GFP mice were used for experiments examining the effects of devaluation on Pavlovian approach (cue-evoked food seeking), Fos expression, and physiological parameters. These mice condition and exhibit food seeking similarly to wild-type mice (Ziminski et al., 2017). Wild-type mice were used for the experiments examining the effects of caloric satiation on Pavlovian approach. All experiments were conducted during the light phase. All animal procedures were performed in accordance with the regulations of the University of Sussex Animal Welfare and Ethical Review Body (AWERB).

\section{Behavioral experiments Apparatus}

All behavioral procedures were conducted in conditioning chambers $(15.9 \times 14 \times 12.7 \mathrm{~cm}$; Med Associates), each enclosed within a sound-attenuating and lightresistant cubicle. The conditioning chamber was fitted with a recessed magazine situated in the center of one side wall, which dispensed $10 \%$ sucrose solution serving as the unconditioned stimulus (US). An infrared beam detected head entries into the magazine. The house light was situated in the side panel and was on for the duration of each training or test session. A mechanical relay served as an auditory (click) conditioned stimulus (CS; Med Associates). Initiation and running of behavioral protocols, including the recording of head entries into the food magazine, was performed using Med-PC IV (Med Associates; RRID:SCR_012156).

\section{Behavioral procedures}

Before conditioning, mice underwent a single session of magazine training, which began following the initial head entry into the food magazine. During this session, they received 40 presentations of $10 \%$ sucrose solution $(\sim 15$ $\mu l)$ in the food magazine on a random interval (RI) 30 schedule to get accustomed to the sucrose delivery procedure. Starting the next day, mice underwent 11-12 Pavlovian conditioning sessions (on average, $24 \mathrm{~min} / \mathrm{ses}-$ sion; one to two times daily in the morning [8:00 A.M. to 12:00 P.M. (noon)] and/or afternoon [12:00 P.M. (noon) to 5:00 P.M.]) over 7 consecutive days. The illumination of the house light indicated the start of each session, which consisted of six 120 s CS presentations (yoked across conditioning chambers), separated by $120 \mathrm{~s} \mathrm{RI}$ intertrial interval (ITI) periods. During each 120 s CS period, $\sim 15 \mu \mathrm{l}$ of $10 \%$ sucrose solution was delivered into the magazine on an $\mathrm{Rl} 30 \mathrm{~s}$ schedule. Following conditioning, mice remained in the colony room for 7-9 d until test day. Three days following the final conditioning session (Fig. 1A), mice were randomly allocated to one of two groups for the remaining 4-6 d for the following: (1) reward-specific devaluation experiments in which all mice continued to be food restricted, and one group of mice (Devalued group) received ad libitum sucrose solution in their home cage, whereas the control (Non-devalued) group received an additional water bottle; and (2) caloric satiation experiments in which one group of mice (ad libitum chow group) received ad libitum chow in their home cage, whereas the Control group continued to be food restricted until test day. On test day, mice underwent Pavlovian approach testing, to assess cue-evoked sucrose seeking, which consisted of a single session that was similar to the conditioning session, but under extinction conditions (i.e., in the absence of sucrose delivery to avoid the interference of acute sucrose consumption).

\section{Fos immunohistochemistry}

Following testing for Pavlovian approach, mice from the devaluation experiments remained in the conditioning chambers for an additional $\sim 1 \mathrm{~h}$ to allow for optimal Fos expression. Subsequently, they were anesthetized using sodium pentobarbital in saline (1:10; $200 \mathrm{mg} / \mathrm{kg}$, i.p.). Mice were transcardially perfused with ice-cold PBS (concentrations in $\mathrm{mm}: \mathrm{NaCl} 137, \mathrm{KCl} 2.7, \mathrm{Na}_{2} \mathrm{HPO}_{4} 10$, and $\left.\mathrm{KH}_{2} \mathrm{PO}_{4} 1.8, \mathrm{pH} 7.4\right)$ for $5 \mathrm{~min}(5 \mathrm{ml} / \mathrm{min})$ and with ice-cold 4\% paraformaldehyde (PFA; catalog \#158127, SigmaAldrich) for $20 \mathrm{~min}(5 \mathrm{ml} / \mathrm{min})$ using a peristaltic pump (Masterflex L/S, Cole Parmer). Thirty minutes after the end of the perfusion, brains were removed, postfixated in $4 \%$ 
A

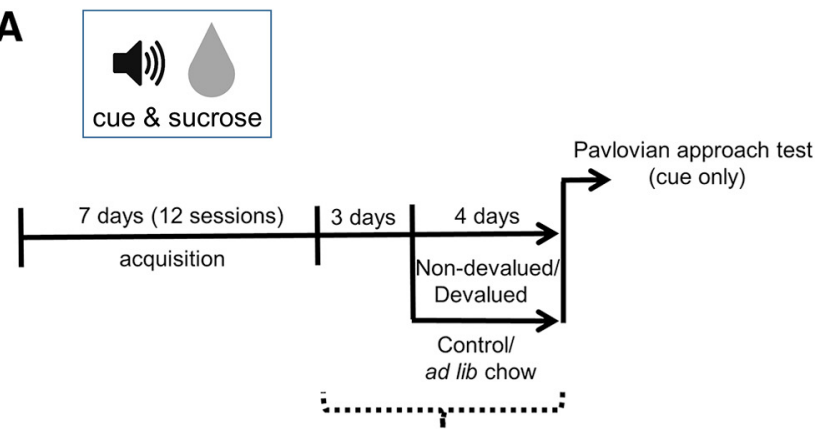

B
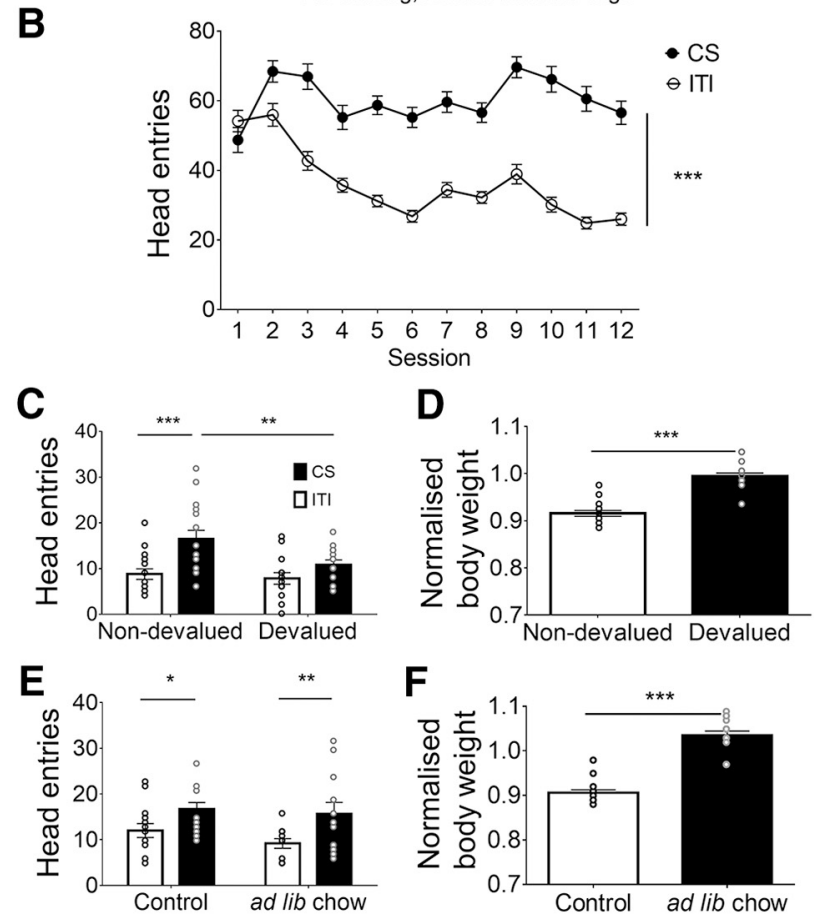

Figure 1. Sucrose reward devaluation, but not caloric satiation, attenuates Pavlovian approach behavior. A, Time line for the Pavlovian approach behavioral paradigm with devaluation and caloric satiation. $\boldsymbol{B}$, The number of head entries in sucrose delivery magazine during acquisition in response to a sucroseassociated cue (CS) is significantly higher than during ITI; $n=32$ asterisks indicate the main effect of trial, $* * * p<0.001$. $\boldsymbol{C}$, The number of head entries during the Pavlovian approach test in Non-devalued and Devalued mice. Head entries during the cue are significantly higher only in the Non-devalued condition. $* * p=0.008$, $* * * p<0.001$. $n=14-16$ /group. $\boldsymbol{D}$, Body weight normalized to free-feeding body weight in Non-devalued mice is significantly lower than in Devalued mice. $* * * p<0.001 . n=16$ per group. $\boldsymbol{E}$, No difference in the number of head entries during the Pavlovian approach test during sucrose-associated CS and ITI between ad libitum (ad lib) chow and Control mice. Head entries during the cue are significantly higher. $* p=0.03, * * p=$ 0.007. $n=12-14 /$ group. $\boldsymbol{F}$, Body weight normalized to free feeding body weight in food-restricted mice is significantly lower than in ad libitum chow mice independent of conditioning. $* * * p$ $<0.001 . n=12-14 /$ group. All values are the mean \pm SEM.

Figure Contributions: M.C.S., J.J.Z., G.M.-S., H.R., and L.S.B. performed experiments; M.C.S. analyzed the data.
PFA at $4^{\circ} \mathrm{C}$ for $\sim 22 \mathrm{~h}$, and then cryoprotected in $30 \%$ sucrose solution in PBS for $3-5 \mathrm{~d}$. Brains were frozen on dry ice and stored at $-80^{\circ} \mathrm{C}$ until further use. Brains were sliced into $30 \mu \mathrm{m}$ coronal sections containing NAc (anteroposterior $1.5 \mathrm{~mm}$ from bregma; Paxinos and Franklin, 2012) using a cryostat (Leica CM 1900, Leica Microsystems) and stored in PBS with sodium azide $(0.02 \%)$ or cryopreservant.

Free-floating slices were washed three times for $10 \mathrm{~min}$ in PBS, incubated in $0.3 \%$ hydrogen peroxide in PBS for 15-20 min to block endogenous peroxidase activity and subsequently washed three times in PBS. To block nonspecific binding sites and permeabilize cell membranes, slices were incubated in 3\% NGST (normal goat serum with Triton X-100; Vector Laboratories) for $1 \mathrm{~h}$. Slices were incubated in primary antibody $(1: 8000$; rabbit anti-c-Fos, sc-52, LOT A2914, Santa Cruz Biotechnology; RRID: $A B \_2106783$ ) in $3 \%$ NGST over night at $4^{\circ} \mathrm{C}$. Next, slices were washed three times in PBS and incubated in the secondary antibody (1:600; biotinylated goat anti-rabbit $\operatorname{lgG} \mathrm{H}+\mathrm{L}$, Vector Laboratories; RRID:AB_2313606) in 1\% NGST for $2 \mathrm{~h}$. After three subsequent washes in PBS, slices were incubated in ABC solution (Vector Laboratories; RRID:AB_2336818) for $1 \mathrm{~h}$ and then washed twice in PBS. Slices were incubated in $0.04 \%$ DAB, $0.05 \%$ nickel ammonium sulfate, and $0.04 \%$ hydrogen peroxide in PBS for $\sim 30 \mathrm{~min}$, and washed three times in PBS. Slices were mounted in water onto Fisherbrand Superfrost Slides (Thermo Fisher Scientific) and dried overnight. For dehydration, slides went through the following steps: $2 \times$ distilled water on ice for $3 \mathrm{~min}, 30 \%$ ethanol for $2 \mathrm{~min}, 60 \%$ ethanol for $2 \mathrm{~min}, 90 \%$ ethanol for $2 \mathrm{~min}$, 95\% ethanol for $2 \mathrm{~min}, 100 \%$ ethanol for $2 \mathrm{~min}, 100 \%$ ethanol for $2 \mathrm{~min}$, and $2 \times$ HistoClear (National Diagnostics) for $10 \mathrm{~min}$. Finally, slides were coverslipped using Histomount (National Diagnostics), dried overnight, and stored at room temperature.

Bright-field images of the NAc shell (hereafter, NAc) were taken using a QI click camera (Qimaging) attached to an Olympus BX53 bright-field microscope and iVisionMac software (version 4.0.15, Biovision Technologies; RRID: SCR_014786). Fos ${ }^{+}$neurons were counted manually bilaterally in a blind manner at a magnification of $100 \times$ using iVision software. Two images were taken per hemisphere (dorsal and ventral), and the numbers of $\mathrm{Fos}^{+}$ neurons were added to get one value per hemisphere. Between hemispheres, values were averaged to get one value per animal. Our Fos analysis was restricted to medial portions of the NAc due to low Fos expression in the lateral NAc.

\section{Electrophysiology}

Ex vivo brain slice preparation

Ninety minutes after the start of Pavlovian approach testing, mice were deeply anaesthetized with ketamine (Anaesktin, Dechra Veterinary Products) and xylazine (Rompun, Bayer Health care) in saline, and then transcardially perfused with ice-cold NMDG solution (in $\mathrm{mm}$ ): NMDG 93, KCl 2.5, $\mathrm{NaH}_{2} \mathrm{PO}_{4}$ 1.2, $\mathrm{NaHCO}_{3} 30$, HEPES 20, D-glucose 25, $\mathrm{C}_{6} \mathrm{H}_{7} \mathrm{NaO}_{6}$ 5, $\mathrm{SC}\left(\mathrm{NH}_{2}\right)_{2} 2, \mathrm{C}_{3} \mathrm{H}_{3} \mathrm{NaO}_{3} 3$, 
Table 1: Basic membrane properties from the NAc shell in Non-devalued and Devalued mice

\begin{tabular}{|c|c|c|c|c|c|c|c|}
\hline & \multicolumn{2}{|c|}{ Non-devalued } & \multicolumn{2}{|c|}{ Devalued } & Interaction & \multicolumn{2}{|c|}{ Main effect } \\
\hline Rheobase (pA) & $115.0 \pm 10.5 * *$ & $63.2 \pm 4.0 * *$ & $96.7 \pm 13.5$ & $91.2 \pm 11.9$ & $F_{(1,37)}=4.57, p=0$. & $F_{(1,37)}=0.20, p=0.66$ & $F_{(1,37)}=7.02, p=0.01$ \\
\hline $\mathrm{AHP}(\mathrm{mV})$ & $-8.9 \pm 0.5$ & $-9.8 \pm 0.8 * * *$ & $-7.7 \pm 0.8$ & $-7.3 \pm 0.8 * * *$ & $F_{(1,38)}=0.78, p=0.38$ & $F_{(1,38)}=0.07, p=0.79$ & $F_{(1,38)}=6.07, p=0.02$ \\
\hline AP half- width (ms) & $1.4 \pm 0.1 * *$ & $1.8 \pm 0.15 * *, * * *$ & $1.4 \pm 0.03$ & $1.4 \pm 0.04 * * *$ & $F_{(1,37)}=2.9, p=0.1$ & $F_{(1,37)}=6.0, p=0.02$ & $F_{(1,37)}=4.31, p=0.04$ \\
\hline AP amplitude (mV) & $67.4 \pm 1.9$ & $58.7 \pm 4.2$ & $65.9 \pm 3.3$ & $63.5 \pm 3.8$ & $F_{(1,37)}=0.82, p=0.37$ & $F_{(1,37)}=2.53, p=0.12$ & $F_{(1,37)}=0.22, p=0.64$ \\
\hline
\end{tabular}

Data in first four columns are expressed as the mean \pm SEM.

$* p<0.05$, $* * p<0.01$, post hoc comparison $\mathrm{GFP}^{+}$vs $\mathrm{GFP}^{-} ; * * * p<0.05$, post hoc comparison Non-devalued vs Devalued

$\mathrm{MgSO}_{4} \mathrm{H}_{2} \mathrm{O} 10$, and $\mathrm{CaCl}_{2} \cdot 2 \mathrm{H}_{2} \mathrm{O} 0.5$, with osmolarity of 300-310 mOsm and pH 7.4 (Ting et al., 2018). Following perfusions, the brains were immersed in ice-cold, filtered NMDG solution for $2 \mathrm{~min}$. The cerebellum was removed, and the brain was mounted onto a stage and placed in a slicing chamber filled with ice-cold NMDG solution. Coronal slices $250 \mu \mathrm{m}$ thick were cut corresponding to $\sim 1.5$ $\mathrm{mm}$ anteroposterior from bregma. Slices were stored in NMDG solution for $5 \mathrm{~min}$ at $32^{\circ} \mathrm{C}$ and then transferred to artificial CSF (aCSF) at room temperature until recording. NMDG solution and aCSF (concentrations in mM: $\mathrm{NaCl}$ 126, $\mathrm{KCl} 4.5, \mathrm{MgCl}_{2} 1, \mathrm{CaCl}_{2} 2.5, \mathrm{NaH}_{2} \mathrm{PO}_{4} 1.2$, D-glucose 11 , and $\mathrm{NaHCO}_{3} 26, \mathrm{pH}$ 7.4) were continuously bubbled with a $95 \% \mathrm{O}_{2} / 5 \% \mathrm{CO}_{2}$ mixture.

\section{Electrophysiological recording}

We recorded from NAc shell medium spiny neurons (MSNs), which are the principal neurons of this area using similar criteria as reported in the study by Ziminski et al. (2017). For NAc current-clamp recordings, the slices were hemisectioned and transferred to the recording chamber continuously refilled with aCSF at $32^{\circ} \mathrm{C}$ (flow rate, $\sim 2$ $\mathrm{ml} / \mathrm{min}$ ). GFP $^{+}$neurons were identified using a $488 \mathrm{~nm}$ laser line from a Revolution XD Spinning Disk Confocal System (Andor) attached to an Olympus BX51W1 microscope (see Fig. 3B). Whole-cell patch-clamp recordings were performed using intracellular solution (ICS; concentrations in mM: K-gluconate $125, \mathrm{KCl} 10$, HEPES 10 , $\mathrm{MgCl}_{2} * 6 \mathrm{H}_{2} \mathrm{O}$ 2, EGTA 1, $\mathrm{CaCl}_{2} * 2 \mathrm{H}_{2} \mathrm{O}_{2}$ 0.1, Mg-ATP 2, and Na-GTP 0.2, at pH 7.25)-filled borosilicate capillary glass pipettes (inner diameter, $0.86 \mathrm{~mm}$; outer diameter, $1.5 \mathrm{~mm}$; resistance 5-7 $\mathrm{M} \Omega$; Sutter Instrument) using a P-97 electrode puller (Sutter Instrument). Alexa Fluor 568 dye (100 $\mu \mathrm{M}$; catalog \#A10437, Thermo Fisher Scientific) was added to the ICS to confirm patched neurons by colocalization with GFP. MSNs were identified using morphology, resting membrane potential (RMP), and action potential (AP) waveform, and held at $-75 \mathrm{mV}$ for the duration of the recordings. The liquid junction potential was $-13.7 \mathrm{mV}$ and was not adjusted for. The currentclamp recording protocol consisted of $800 \mathrm{~ms}$ current injections starting at $-60 \mathrm{pA}$ and increasing in $4 \mathrm{pA}$ steps.

Data were collected with a Multiclamp 700B amplifier (Molecular Devices), and WinEDR (version 3.7.5) and WinWCP Software (version 5.2.2; courtesy of Dr. John Dempster, University of Strathclyde, Glasgow, UK; http:// spider.science.strath.ac.uk/sipbs/software_ses.htm;
RRID: SCR_014713). Signals were digitized at $10 \mathrm{kHz}$ and filtered at $5 \mathrm{kHz}$ (PCl 6024E, National Instruments) and low-frequency noise was filtered out using a HumBug (Quest Scientific) module. The input resistance (Ri) was calculated as the slope of the $I-V$ curve between -60 and 20 pA injections. Rheobase was calculated manually. Spike kinetics (amplitude and half-width) and afterhyperpolarization (AHP) were calculated using Mini Analysis Software (version 6.0; Synaptosoft; RRID:SCR_002184), and spike counts were calculated using Stimfit 0.14 software (Python 2.7.9; Guzman et al., 2014). The basic membrane properties are summarized in Table 1. The number of $\mathrm{GFP}^{+}$and $\mathrm{GFP}^{-}$neurons recorded per mouse was kept approximately constant at two to four neurons in voltage-clamp recordings and four to six neurons in current-clamp recordings, and the order of recordings was counterbalanced.

Voltage-clamp recordings were conducted in the presence of the GABA $A_{A}$ receptor channel blocker picrotoxin (100 $\mu \mathrm{M}$; Sigma-Aldrich) using the following ICS (in $\mathrm{mm}$ ): spermine $0.1, \mathrm{CsCH}_{3} \mathrm{SO} 3120, \mathrm{NaCl} 5$, TEA-Cl 10, HEPES 10, EGTA 1.1, MgATP 4, Na-GTP 0.3, and QX314 4.6 (Lidocaine, Sigma-Aldrich). Spontaneous EPSCs (sEPSCs) were analyzed over a $30 \mathrm{~s}$ period. Responses were evoked through bipolar stimulating electrodes (CBASD75, $\mathrm{FHC}$ ), within $400 \mu \mathrm{m}$ of the neuron with $0.1 \mathrm{~ms}$ pulses at $0.033 \mathrm{~Hz}$. Series resistance was monitored using $-10 \mathrm{mV}$ voltage steps $(100 \mathrm{~ms})$, and only neurons maintaining stable access $(<15 \%$ change) were included in the analyses. Paired-pulse ratios (PPRs) were calculated by stimulating twice in succession and dividing second peak by the first peak (average of triplicate) across ITIs of 20, 40, $60,80,100,150$, and 200 ms. AMPA receptor/NMDA receptor (AMPAR/NMDAR) current ratios were calculated from the averages of $10-20$ evoked EPSCs at $+40 \mathrm{mV}$ with and without D-APV (NMDA receptor antagonist, 50 $\mu \mathrm{M}$; Hello Bio). For each neuron, the AMPAR current (with $D-A P V$ ) was subtracted from the combined current (without D-APV) to yield the NMDAR current (Koya et al., 2012). The AMPAR current peak was divided by the NMDAR current peak to yield AMPAR/NMDAR current ratios. AMPAR rectification curves were produced by averaging triplicate stimulations at $-80,-60,-40,-20,0,20$, and $40 \mathrm{mV}$ in the presence of D-APV. The AMPAR rectification index was calculated by dividing the EPSC peak amplitude at $-80 \mathrm{mV}$ by the peak amplitude at $+40 \mathrm{mV}$. The ratio of the chord conductance $(G=I-V)$ was calculated 
by dividing the chord conductance at $+40 \mathrm{mV}$ by the chord conductance at $-80 \mathrm{mV}\left(\mathrm{G}_{+40 \mathrm{mv}} / \mathrm{G}_{-80 \mathrm{mv}}\right)$. Traces in figures have stimulus artifacts removed.

\section{Experimental design and statistical analysis}

Data were analyzed and visualized using GraphPad Prism 6 (GraphPad software, RRID:SCR_002798), SPSS (IBM SPSS statistics; RRID:SCR_002865), and Excel (Microsoft). Spontaneous EPSCs were analyzed using Mini Analysis Software (version 6.0; Synaptosoft; RRID: SCR_002184), whereas evoked EPSCs (e.g., PPRs) were analyzed using WinWCP Software. Statistical analyses are summarized in Table 2. All data are presented as the mean \pm SEM. Data points exceeding \pm 2 SDs or greater from the mean were excluded from the analyses. Group data are presented as the mean \pm SEM. ANOVAs were followed up by Fisher's least significant difference test.

\section{Behavioral data}

The total number of head entries into the sucrose delivery magazine during acquisition were analyzed using a two-way repeated-measures ANOVA including cue presentation (ITI, CS) and session (1-12) as within-subjects factors. Two-way mixed ANOVAs were used to test for pre-existing differences in a Pavlovian approach, using session (1-12) as within-subjects factor and caloric satiation (control, ad libitum chow) or devaluation (Nondevalued, Devalued) as between-subjects factor. The test data were analyzed using two-way mixed ANOVAs using cue presentation (ITI, CS) as a within-subjects factor and devaluation (Non-devalued, Devalued) or caloric satiation (Control, ad libitum chow) as a between-subjects factor. Body weights were analyzed using unpaired two-tailed $t$ tests. A total of four mice from the ad libitum chow and Devalued groups were excluded from the test analyses due to equipment malfunction.

\section{Fos expression}

Fos quantification data were analyzed using a twotailed $t$ test comparing the number of $\mathrm{Fos}^{+}$neurons per square millimeter between Non-devalued and Devalued conditions. Brain sections from two mice were damaged and could not be used for cell quantification.

\section{Electrophysiology}

Spike counts and $I-V$ curves were first analyzed using a three-way mixed ANOVA with devaluation (Non-devalued, Devalued) and GFP (+/-) as between-subjects factors, and current step as the within-subjects factor. This was followed up by two-way mixed ANOVAs using current step as a within-subjects factor and GFP (+/-) or devaluation (Nondevalued, Devalued) as a between-subjects factor.

RMP, rheobase, Ri, AHP, spike amplitude, and halfwidth were analyzed using two-way ANOVAs with devaluation (Non-devalued, Devalued) and GFP (+/-) as between-subject factors. sEPSC frequency and amplitude, and AMPAR rectification index were analyzed using two-way ANOVAs with devaluation (Non-devalued, Devalued) and GFP (+/ - ) as between-subjects factors. The ratio of $\mathrm{G}=I-V$ at $+40 \mathrm{mV}$ over $-80 \mathrm{mV}\left(\mathrm{G}_{+40 \mathrm{mV}} / \mathrm{G}_{-80 \mathrm{mV}}\right)$ was analyzed using a one-sample $t$ test against the pop- ulation mean of 1 , which indicates a lack of rectification (Bonferroni corrections were used to control for multiple comparisons). PPRs were analyzed using a three-way mixed ANOVA with devaluation (Non-devalued, Devalued) and GFP (+/-) as between-subjects factors and interstimulus interval as a within-subjects factor. AMPAR/NMDAR current ratios and SEPSC parameters were analyzed using a twoway ANOVA with devaluation (Non-devalued, Devalued) and GFP (+/-) as between-subjects factors.

\section{Results}

\section{Acquisition of Pavlovian conditioning}

We assessed the establishment of a cue-sucrose association following 12 sessions of Pavlovian conditioning, during which an auditory cue (clicker) was repeatedly paired with $10 \%$ sucrose solution delivery (Fig. 1A). With conditioning, mice made a significantly greater number of head entries into the sucrose delivery magazine during the CS period (cue and sucrose presentation) versus the nonCS/ITI period; this difference was mainly due to a progressive decrease in responding during the ITI as conditioning progressed (Fig. 1B). A two-way repeatedmeasures ANOVA revealed a significant interaction of cue presentation (CS, ITI) and session $\left(F_{(11,341)}=18.12, p<\right.$ $0.0001)$, and significant main effects of cue presentation $\left(F_{(1,31)}=321, p<0.0001\right)$ and session $\left(F_{(11,341)}=9.957\right.$, $p<0.0001)$. This finding indicates that mice learned the association between the cue and sucrose delivery.

\section{Reward-specific devaluation attenuates Pavlovian approach}

Seven days after the last acquisition session and after 4-6 d of either ad libitum chow or sucrose solution in the home cage, mice underwent Pavlovian approach testing under extinction conditions (Fig. 1A).

We first assessed the effect of sucrose devaluation on Pavlovian approach. A two-way mixed ANOVA showed a significant interaction of cue presentation $\times$ devaluation $\left(F_{(1,28)}=5.275, p=0.0293\right)$ and a significant effect of cue presentation $\left(F_{(1,28)}=27.84, p<0.0001\right)$. Post hoc group differences, indicating a reduction of cue-evoked sucrose seeking in Devalued mice, are presented in Figure $1 C$. Importantly, no pre-existing differences between groups were detected during acquisition (interaction of devaluation $\times$ session: $F_{(11,330)}=0.6798, p=0.7577$; session: $F_{(11,330)}=26.67, p<0.0001$; devaluation: $F_{(1,30)}=0.016$, $p=0.9002)$.

Frequent sucrose consumption results in weight gain (Te Morenga et al., 2012). Thus, as a measure for sucrose consumption, we measured the body weights of Devalued mice following ad libitum sucrose consumption and compared them with those of Non-devalued mice. A $t$ test $\left(t_{(30)}=8.629, p<0.0001\right)$ revealed that mice in the Devalued group exhibited significantly higher body weights than their Non-devalued counterparts (Fig. 1D), indicating that mice in the Devalued group consumed a significant amount of sucrose. 

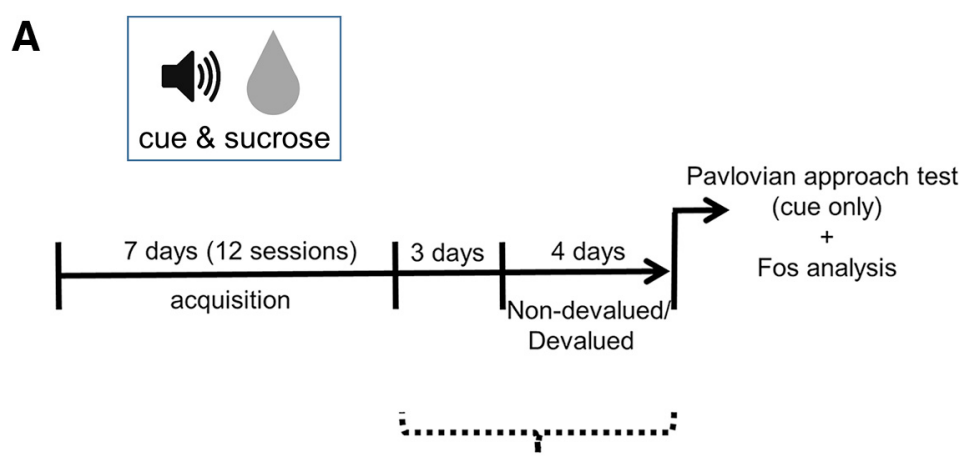

No training, remain in home cage

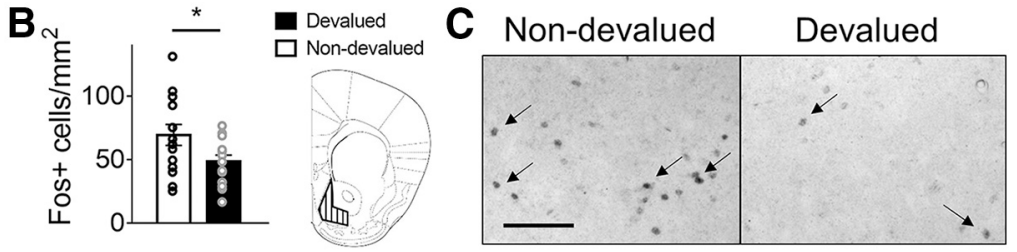

Figure 2. Fos expression in the NAc shell. $\boldsymbol{A}$, Time line for Pavlovian approach behavioral paradigm with devaluation and subsequent Fos analysis. $\boldsymbol{B}$, Reward-specific devaluation decreased the Fos expression. $N=14 /$ group, $* p<0.05$. $\boldsymbol{C}$, Representative images of Fos staining in NAc shell in the Non-devalued and Devalued groups. All values are the mean \pm SEM. Arrows indicate exemplary Fos ${ }^{+}$ cells. Scale bar, $100 \mu \mathrm{m}$. Schematic overview was modified after Paxinos and Franklin (2012).

Figure Contributions: M.C.S. performed experiments and analyzed the data.

\section{Caloric satiation does not modulate Pavlovian approach}

Next, we assessed whether increased caloric consumption alone would result in reduced cue reactivity. To this end, we trained an additional group of mice using the same behavioral procedure as above, but instead of sucrose we provided them with ad libitum access to chow in their home cage. Caloric satiation did not modulate cueevoked sucrose seeking (Fig. 1E), but cue presentations increased the number of head entries during the CS, as shown by a two-way ANOVA (interaction cue presentation $\times$ caloric satiation: $F_{(1,24)}=0.3335, p=0.569$; cue presentation: $F_{(1,24)}=14.26, p=0.0009$; caloric satiation: $\left.F_{(1,24)}=1.081, p=0.3089\right)$. Post hoc comparisons are shown in Figure 1E. Again, no pre-existing differences between groups were detected during acquisition (interaction caloric satiation $\times$ session: $F_{(11,308)}=0.8548, p=$ 0.5853; session: $F_{(11,308)}=10.54, p<0.0001$; caloric satiation: $\left.F_{(1,28)}=0.907, p=0.3491\right)$. Also, similar to $a d$ libitum sucrose consumption, ad libitum chow consumption also increased body weight $\left(t_{(26)}=10.62, p<0.001\right.$; Fig. 1F). This suggests that cue-evoked sucrose seeking was not attenuated by caloric need alone.

\section{Devaluation attenuates NAc Fos expression}

Next, we assessed the effects of reward-specific devaluation on neuronal ensemble activity in the NAc by examining the number of Fos-expressing neurons (Fig. $2 A)$. A $t$ test revealed a significant reduction in $\mathrm{Fos}^{+}$ neurons in NAc $\left(t_{(27)}=2.376, p=0.0249\right)$ in the Devalued group compared with the Non-devalued group, indicating that a smaller ensemble was recruited in the NAc following reward-specific devaluation (Fig. 2B,C).

\section{Devaluation is associated with lack of excitability differences between ensemble and non-ensemble neurons}

In a separate cohort of mice, we assessed the excitability of cue-responsive, GFP ${ }^{+}$ensemble and surrounding GFP $^{-}$non-ensemble MSNs 90 min following the initiation of Pavlovian approach testing (Fig. $3 A$ ). We injected increasing amounts of current into the neurons and quantified the number of action potentials fired in response to assess the firing capacity of these neurons (Fig. 3). A three-way mixed ANOVA showed an interaction of current step $\times$ devaluation $\times \operatorname{GFP}\left(F_{(8,304)}=3.115, p=\right.$ $0.002)$, an interaction of current step $\times \operatorname{GFP}\left(F_{(8,304)}=\right.$ $6.784, p<0.0001)$, as well as a significant main effect of current step $\left(F_{(8,304)}=53.88, p<0.0001\right)$ and GFP $\left(F_{(1,38)}=\right.$ $8.364, p=0.006)$, but not devaluation $\left(F_{(1,38)}=0.012, p=\right.$ $0.912)$. To determine what is driving this three-way interaction, we further conducted a two-way ANOVA comparing the firing rates (spike counts) of $\mathrm{GFP}^{+}$and $\mathrm{GFP}^{-}$ neurons within Non-devalued mice separately. This revealed an interaction of current step $\times \operatorname{GFP}\left(F_{(8,152)}=\right.$ $11.84, p<0.0001)$, as well main effects of current step $\left(F_{(8,152)}=35.64, p<0.0001\right)$ and GFP $\left(F_{(1,19)}=18.57, p=\right.$ 0.0004; Fig. $3 C$ ). This indicates that in Non-devalued mice, GFP ${ }^{+}$and GFP $^{-}$neurons differed significantly in firing capacity. A similar ANOVA comparing $\mathrm{GFP}^{+}$and GFP $^{-}$neurons within the Devalued group yielded a main effect of current step $\left(F_{(8,152)}=21.43, p<0.0001\right)$, but no effect of GFP $\left(F_{(1,19)}=0.3584, p=0.5565\right)$ or interaction $\left(F_{(8,152)}=0.5413, p=0.8239 ;\right.$ Fig. $\left.3 D\right)$. Hence, in the Devalued group, GFP ${ }^{+}$and GFP ${ }^{-}$neurons did not differ in firing capacity. Post hoc tests are indicated in Figure 3, C and $D$. Together, these results indicate that differences in 


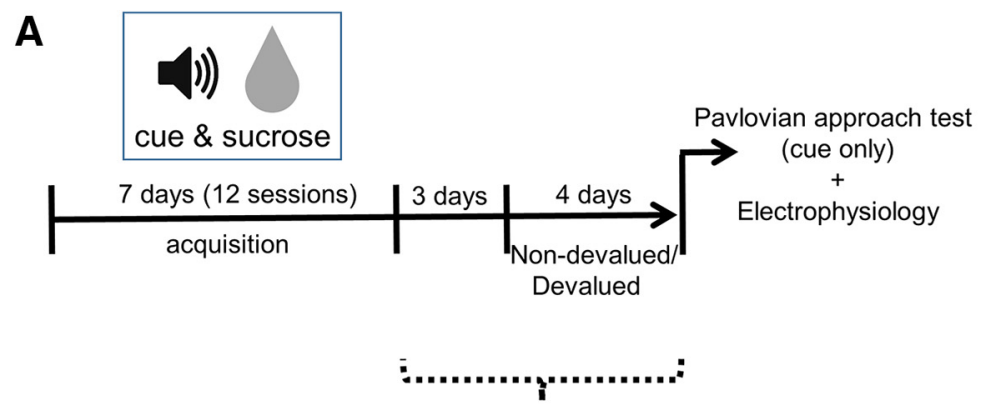

No training, remain in home cage
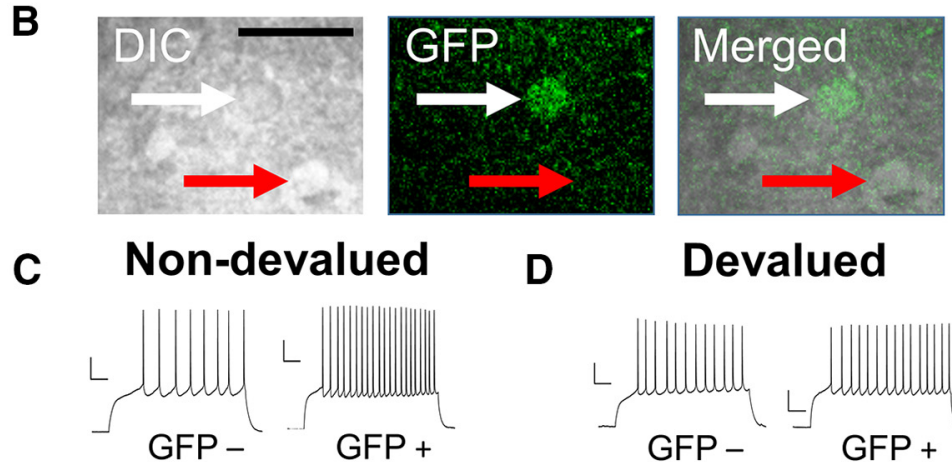

D Devalued
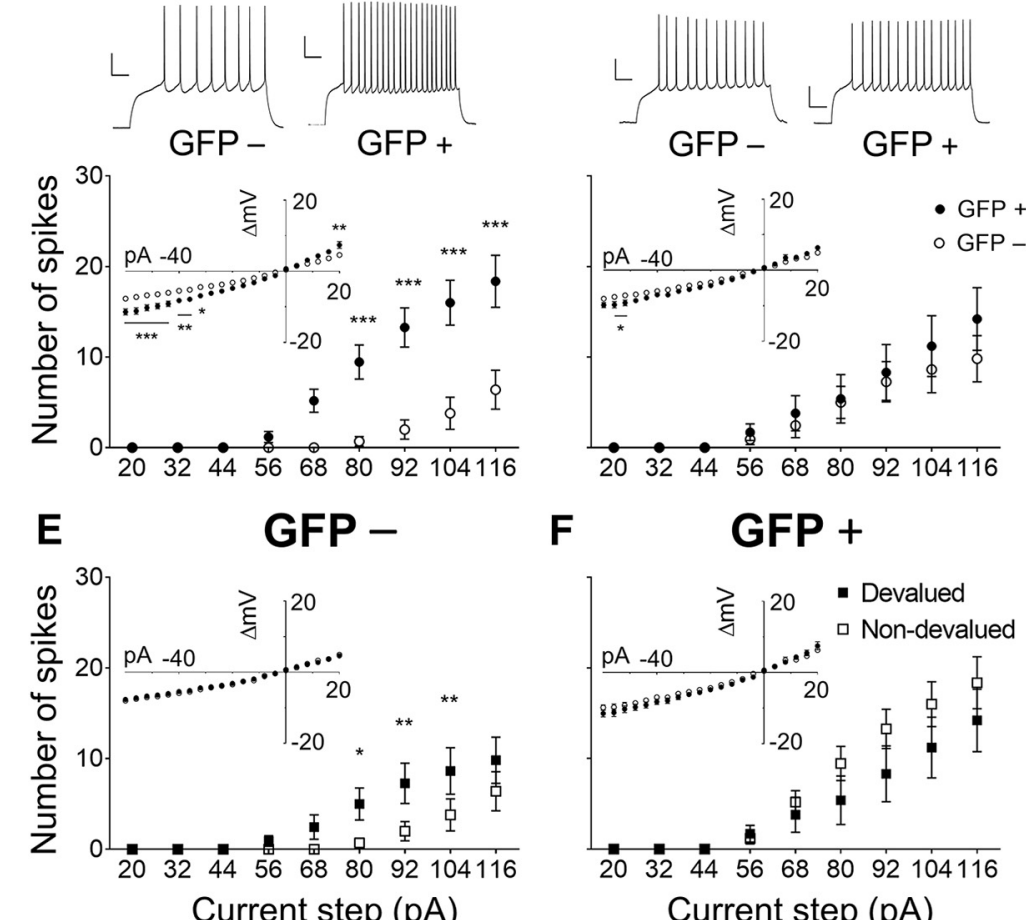

$\mathbf{F}$

GFP +

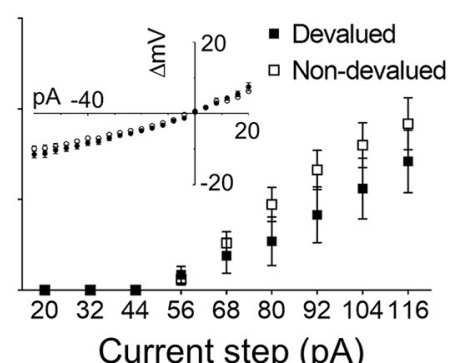

Figure 3. The increased excitability of $\mathrm{GFP}^{+}$neurons compared with surrounding $\mathrm{GFP}^{-}$neurons in NAc shell is attenuated by reward devaluation. A, Time line for the Pavlovian approach behavioral paradigm with devaluation. $\boldsymbol{B}$, Differential interference contrast (DIC)

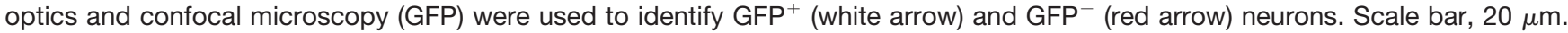
$\boldsymbol{C}$, In the Non-devalued group, GFP ${ }^{+}$cells exhibit increased spiking in response to increasing current injections compared with surrounding GFP ${ }^{-}$cells. The $I-V$ curve (inlay) for GFP $^{+}$cells are shifted in positive and negative current steps, but not in the intermediate range $\left(\mathrm{GFP}^{-}, n=10 / 6\right.$; $\left.\mathrm{GFP}^{+}, n=11 / 6\right)$. Representative traces from injections at $116 \mathrm{pA}$ (top). $\boldsymbol{D}$, After sucrose devaluation, there is no difference in firing capacity between $\mathrm{GFP}^{+}$and $\mathrm{GFP}^{-}$cells. Only a mild downward shift is observed for the $I-V$ curves (inlay) from GFP ${ }^{+}$and GFP ${ }^{-}$cells (GFP ${ }^{-}, n=11 / 9 ; \mathrm{GFP}^{+}, n=11 / 8$ ). Representative traces from injections at $116 \mathrm{pA}$ (top). $\boldsymbol{E}, \mathrm{GFP}^{-}$cells exhibit an increased number of spikes after sucrose devaluation. $\boldsymbol{F}$, There is no difference in firing capacity or $I-V$ curves (inlay) in $\mathrm{GFP}^{+}$cells between the Devalued and Non-devalued groups. $* p<0.05, * * p<0.01, * * * p<0.001$. All values are the mean \pm $\mathrm{SEM}$, and values to the right of $\mathrm{GFP}^{-}$and $\mathrm{GFP}^{+}$denote the number of cells recorded/number of mice used. Calibration: $20 \mathrm{mV}$, $100 \mathrm{~ms}$.

Figure Contributions: M.C.S. performed experiments; M.C.S. and J.J.Z. analyzed the data. 
excitability between $\mathrm{GFP}^{+}$and $\mathrm{GFP}^{-}$neurons are eliminated following reward-specific devaluation.

Excitability changes in both ensemble and nonensemble neurons underlie alterations in appetitive learning (Whitaker et al., 2017; Ziminski et al., 2017, 2018). Therefore, we compared the spike counts of $\mathrm{GFP}^{+}$and GFP $^{-}$neurons separately across conditions. For the GFP $^{-}$non-ensemble neurons (Fig. 3E), we discovered an interaction of current step $\times$ devaluation $\left(F_{(8,152)}=2.048\right.$, $p=0.0444)$ and a main effect of current step $\left(F_{(8,152)}=\right.$ 15.91, $p<0.0001$ ), but no main effect of devaluation $\left(F_{(1,19)}=3.271, p=0.0864\right)$. Post hoc analysis revealed a slight, but significant, increase in spike number in GFP ${ }^{-}$ neurons from the Devalued group, which was not accompanied by any changes in the $I-V$ curves or any of the active and passive membrane properties (Figs. 3, 4). For the $\mathrm{GFP}^{+}$ensemble (Fig. 3F), two-way mixed ANOVAs revealed no significant interaction of current step $\times$ devaluation $\left(F_{(8,152)}=1.33, p=0.2324\right)$ or main effect of devaluation $\left(F_{(1,19)}=1.152, p=0.2966\right)$, but did reveal a significant main effect of current step $\left(F_{(8,152)}=38.45, p<\right.$ $0.0001)$. These findings indicate that a slight increase in excitability in $\mathrm{GFP}^{-}$non-ensemble neurons contributed to the lack of excitability differences between the $\mathrm{GFP}^{+}$and $\mathrm{GFP}^{-}$neurons as a function of reward-specific devaluation.

Analysis of $I-V$ curves with a three-way mixed ANOVA did not reveal an interaction of current step $\times$ GFP $\times$ devaluation $\left(F_{(20,780)}=1.212, p=0.236\right)$, but did reveal a significant interaction of current step $\times \operatorname{GFP}\left(F_{(20,780)}=\right.$ 11.031, $p<0.0001$ ), as well as a significant effect of current step $\left(F_{(20,780)}=430.768, p<0.0001\right)$ and GFP $\left(F_{(1,39)}=16.829, p<0.0001\right)$, but not of devaluation $\left(F_{(1,39)}=0.789, p=0.38\right)$. To determine what is driving these effects, further analysis using a two-way ANOVA comparing $\mathrm{GFP}^{+}$and $\mathrm{GFP}^{-}$neurons separately within Non-devalued and Devalued groups was conducted. It revealed a significant interaction of current step $\times$ GFP $\left(F_{(20,360)}=7.951, p<0.0001\right)$ as well as main effects of each factor (current step: $F_{(20,360)}=185.5, p<0.0001$; GFP: $\left.F_{(1,18)}=11.5, p=0.0033\right)$ in the Non-devalued group (Fig. $3 C$, inlay), which was similar to the effect observed in the number of spikes. Post hoc comparisons between $\mathrm{GFP}^{+}$and $\mathrm{GFP}^{-}$neurons in negative and positive potential are indicated in Figure $3 C$ (inlay). In the Devalued group, a two-way ANOVA comparing GFP ${ }^{+}$and $\mathrm{GFP}^{-}$neurons yielded an interaction of current step $\times$ $\operatorname{GFP}\left(F_{(20,380)}=2.931, p<0.0001\right)$ as well as a main effect of both factors (current step: $F_{(20,380)}=217.6, p<0.0001$; GFP: $F_{(1,19)}=4.504, p=0.0472$; Fig. $3 D$, inlay). Post hoc tests are indicated in the Figure $3 D$ inlay. Similar to our previous analysis of excitability, we next conducted additional two-way ANOVAs in $\mathrm{GFP}^{+}$or $\mathrm{GFP}^{-}$neurons between the Devalued and Non-devalued groups. For both $\mathrm{GFP}^{+}$and $\mathrm{GFP}^{-}$neurons, no significant interaction or effect of devaluation but an effect of current step $\left(\mathrm{GFP}^{+}\right.$: $F_{(20,360)}=177.5, p<0.0001, \mathrm{GFP}^{-}: F_{(20,380)}=267.7, p<$ $0.0001)$ were revealed (Fig. $3 E, F$, inlays). In summary, the differences in the $I-V$ curves of $\mathrm{GFP}^{+}$and $\mathrm{GFP}^{-}$neurons seen before devaluation were still present afterward, but
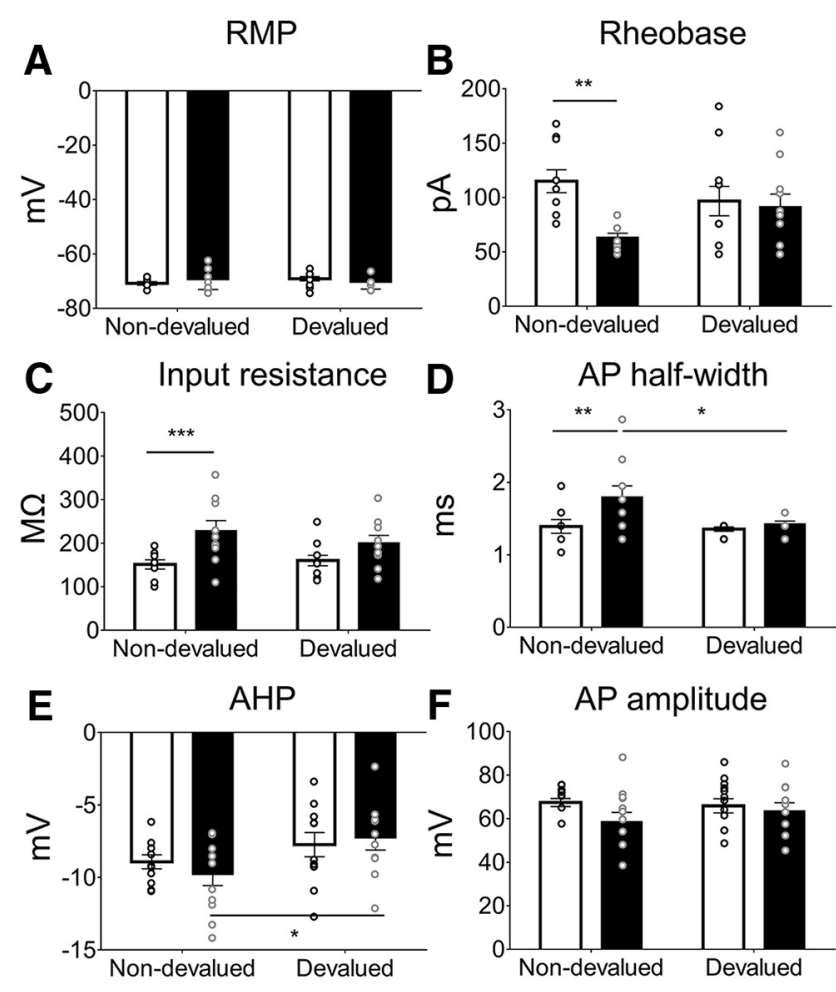

F AP amplitude
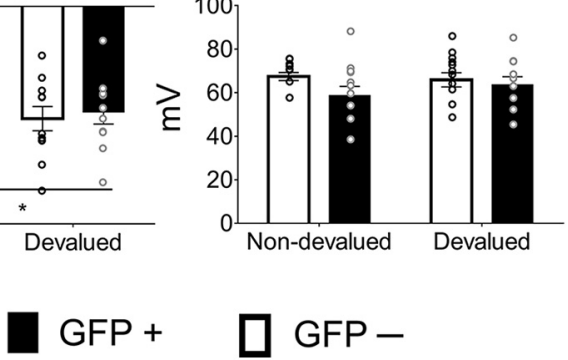

Figure 4. Basic passive membrane and action potential parameters in $\mathrm{GFP}^{+}$and $\mathrm{GFP}^{-}$cells with and without devaluation. $\boldsymbol{A}$, RMP was unchanged by devaluation or ensemble identity. $\boldsymbol{B}$, Rheobase was lower in $\mathrm{GFP}^{+}$compared with $\mathrm{GFP}^{-}$cells without devaluation; $* * p=0.0047$ (Non-devalued: GFP ${ }^{-}, n=9 / 5$; $\mathrm{GFP}^{+}, n=10 / 6$; Devalued: GFP ${ }^{-}, n=11 / 9$; GFP $\left.{ }^{+}, n=10 / 8\right)$. C, Input resistance was specifically increased in $\mathrm{GFP}^{+}$cells without devaluation; $* * p=0.0021$ (Non-devalued: GFP ${ }^{-}, n=10 / 6$; $\mathrm{GFP}^{+}, n=10 / 6$; Devalued: GFP ${ }^{-}, n=11 / 9$; $\left.\mathrm{GFP}^{+}, n=10 / 8\right)$. $\boldsymbol{D}$, AP half-width was specifically increased in Non-devalued GFP ${ }^{+}$ neurons; $* p=0.0103, * * p=0.0052$ (Non-devalued: $\mathrm{GFP}^{-}, n=$ 10/6; $\mathrm{GFP}^{+}, n=11 / 6$; Devalued: GFP ${ }^{-}, n=10 / 9$; $\mathrm{GFP}^{+}, n=$ 10/8). E, AHP was unchanged by devaluation or ensemble identity. $\boldsymbol{F}$, AP amplitude was unchanged by devaluation or ensemble identity. All values are the mean \pm SEM, values to the right of GFP $^{-}$and GFP ${ }^{+}$denote the number of cells recorded/number of mice used, asterisks indicate post hoc comparisons after twoway ANOVAs.

Figure Contributions: M.C.S. performed experiments; M.C.S. analyzed the data.

were less pronounced and restricted to negative potentials.

To investigate the source of the differences in firing capacity, we examined the RMP, rheobase, Ri, AHP, and AP half-width and amplitude of $\mathrm{GFP}^{+}$and $\mathrm{GFP}^{-}$neurons from the Non-devalued and Devalued groups using twoway ANOVAs (Fig. 4, Table 1). For rheobase $\left(F_{(1,37)}=4.57\right.$, $p=0.0392$; Fig. $4 B$ ), but for none of the remaining parameters, we found a significant interaction of devaluation $X$ GFP. Post hoc testing revealed decreased rheobase in $\mathrm{GFP}^{+}$neurons compared with $\mathrm{GFP}^{-}$neurons in the Nondevalued, but not in the Devalued group. This suggests 
that devaluation eliminated the differences in the minimum amount of current needed for spiking between ensemble and non-ensemble neurons (Table 1). We only found a main effect of GFP for $\operatorname{Ri}\left(F_{(1,38)}=13.47, p=\right.$ 0.0007; Fig. 4C) and AP half-width $\left(F_{(1,37)}=6.004, p=\right.$ 0.012 ; Fig. 4D). There was a main effect for devaluation for $\operatorname{AHP}\left(F_{(1,38)}=6.07, p=0.02\right.$; Fig. 4E), AP half-width $\left(F_{(1,37)}=4.31, p=0.04\right.$; Fig. $\left.4 D\right)$, and rheobase $\left(F_{(1,37)}=\right.$ 7.02, $p=0.01$; Fig. 4B). Post hoc tests are indicated in Figure 4 and Table 1. We did not reveal any effects on RMP and AP amplitude (Fig. 4A,F). Hence, devaluation did not modulate these properties in an ensemble-specific manner.

\section{Devaluation does not modulate synaptic properties in an ensemble-specific manner}

We next investigated the synaptic properties of $\mathrm{GFP}^{+}$ and GFP $^{-}$neurons in Non-devalued and Devalued groups. We first measured the synaptic strength in these neurons by assessing the AMPAR/NMDAR ratios. A twoway ANOVA did not reveal a significant interaction of devaluation $\times \operatorname{GFP}\left(F_{(1,19)}=0.35, p=0.56\right.$; Fig. $\left.5 A\right)$, indicating a lack of differences in synaptic strength across ensembles and conditions. The insertion of GluA2-lacking AMPARs enhances excitatory transmission, and neurons expressing these receptors display inward rectification (Cull-Candy et al., 2006). Therefore, we measured rectification of AMPAR EPSC by dividing the EPSC amplitude at $-80 \mathrm{mV}$ by the amplitude at $+40 \mathrm{mV}$ in the presence of the NMDA antagonist APV. We observed no significant interaction of GFP $\times$ devaluation $\left(F_{(1,15)}=0.37, p=0.55\right.$; Fig. $5 B$ ), indicating no differences in the expression of GluA2-lacking AMPARs across ensembles and conditions.

Previous studies have shown that food restriction and palatable food consumption increase the expression of GluA2-lacking AMPARs in the nucleus accumbens (Oginsky et al., 2016; Ouyang et al., 2017). As such, we examined whether inward rectification was generally present in Devalued and Non-devalued mice that underwent both food restriction and repeated sucrose consumption during training. We calculated the ratio of $G$ at +40 over -80 $\mathrm{mV}\left(\mathrm{G}_{+40 \mathrm{mv}} / \mathrm{G}_{-80 \mathrm{mv}}\right)$. If rectification is present, then this value is $<1$. A one-sample $t$ test against a population of mean of 1 revealed that in the Devalued group, GFP ${ }^{+}$ neurons did not display rectification $\left(0.70 \pm 0.11 ; t_{(4)}=\right.$ 2.67, $p=0.0559)$, but was observed in $\mathrm{GFP}^{-}$neurons $\left(0.58 \pm 0.09 ; t_{(4)}=4.48, p=0.0110\right)$. Also, rectification was observed in $\mathrm{GFP}^{+}$and $\mathrm{GFP}^{-}$neurons in the Nondevalued group $\left(\mathrm{GFP}^{+}: 0.57 \pm 0.02, t_{(3)}=20.16, p=\right.$ 0.0003; GFP $\left.{ }^{-}: 0.56 \pm 0.04, t_{(4)}=10.32, p=0.0005\right)$. Collectively, these data suggest that devaluation did not modulate synaptic strength and AMPA receptor function on NAc ensembles. However, these data suggest that we observed widespread expression of GluA2-lacking AMPARs, as indicated by rectification in $\mathrm{GFP}^{-}$non-ensemble neurons regardless of devaluation.

Next, we examined the sEPSC frequency and amplitude. We observed no significant interaction of GFP $\times$ devaluation in sEPSC frequency $\left(F_{(1,65)}=0.03, p=0.85\right.$;
Fig. $5 C)$ or amplitude $\left(F_{(1,65)}=0.71, p=0.40\right.$; Fig. $\left.5 C\right)$. There was a main effect of devaluation for sEPSC frequency $\left(F_{(1,65)}=6.46, p<0.05\right)$, suggesting a generalized decrease in SEPSC frequency in Devalued mice (Fig. $5 C$ ). Finally, we observed no interaction or main effects in presynaptic release probability as measured using the PPR (GFP $\times$ devaluation $\times$ interstimulus interval: $F_{(6,180)}=0.53$, $p=0.78)$, suggesting that the group differences in sEPSC frequency were not driven by presynaptic adaptations (Fig. 5D).

\section{Discussion}

Here we examined the effects of devaluation on ensemble plasticity at the levels of recruitment, excitability, and synaptic physiology in sucrose-conditioned Fos-GFP mice. After conditioning, we provided mice with $4 \mathrm{~d}$ of ad libitum access to sucrose or standard chow. Sucrose access, but not caloric satiation alone, attenuated cueevoked sucrose seeking and hence led to devaluation. This reward-specific devaluation (1) reduced the size of the behaviorally activated NAc shell neuronal ensemble and (2) eliminated differences in excitability between ensemble and non-ensemble neurons that were observed under Non-devalued conditions. Interestingly, devaluation did not alter any ensemble-specific synaptic alterations. Our findings provide new insights into how changes in the rewarding properties of food modulate cue-evoked sucrose seeking by potentially modifying the background excitability of NAc non-ensemble neurons.

\section{Implications and mechanisms of reduced cue- evoked sucrose seeking and ensemble size following devaluation}

Reward-specific devaluation, but not general caloric satiation alone, decreased cue-evoked sucrose seeking. Hence, the incentive and/or hedonic properties of sucrose, but not homeostatic need, may control this behavioral change. The incentive properties relate to the inclination to seek food, whereas the hedonic properties relate to the pleasurable properties associated with food consumption (Castro et al., 2015). One possibility then is that ad libitum access to sucrose decreased the incentive properties of the sucrose-associated cue. In support, selective satiation reduces breakpoints on a progressive ratio appetitive task (Baxter et al., 2000). Alternatively, mice in our study may have updated the reward representation according to the new and less attractive value and adapted their food seeking because sucrose overconsumption led to decreases in palatability or hedonic properties (Thompson et al., 1976; Strickland et al., 2018). To directly determine the factors that decreased sucrose seeking, a future study incorporating sucrose consumption and orofacial reactivity during a sucrose consumption test would be needed (Berridge et al., 1981; Johnson et al., 2009; Castro et al., 2015).

Devaluation decreased NAc Fos expression consistent with the role of NAc in mediating the hedonic and incentive properties of sucrose and associated cues (Kelley et al., 1996; Taha, 2005; Cacciapaglia et al., 2012). At the 

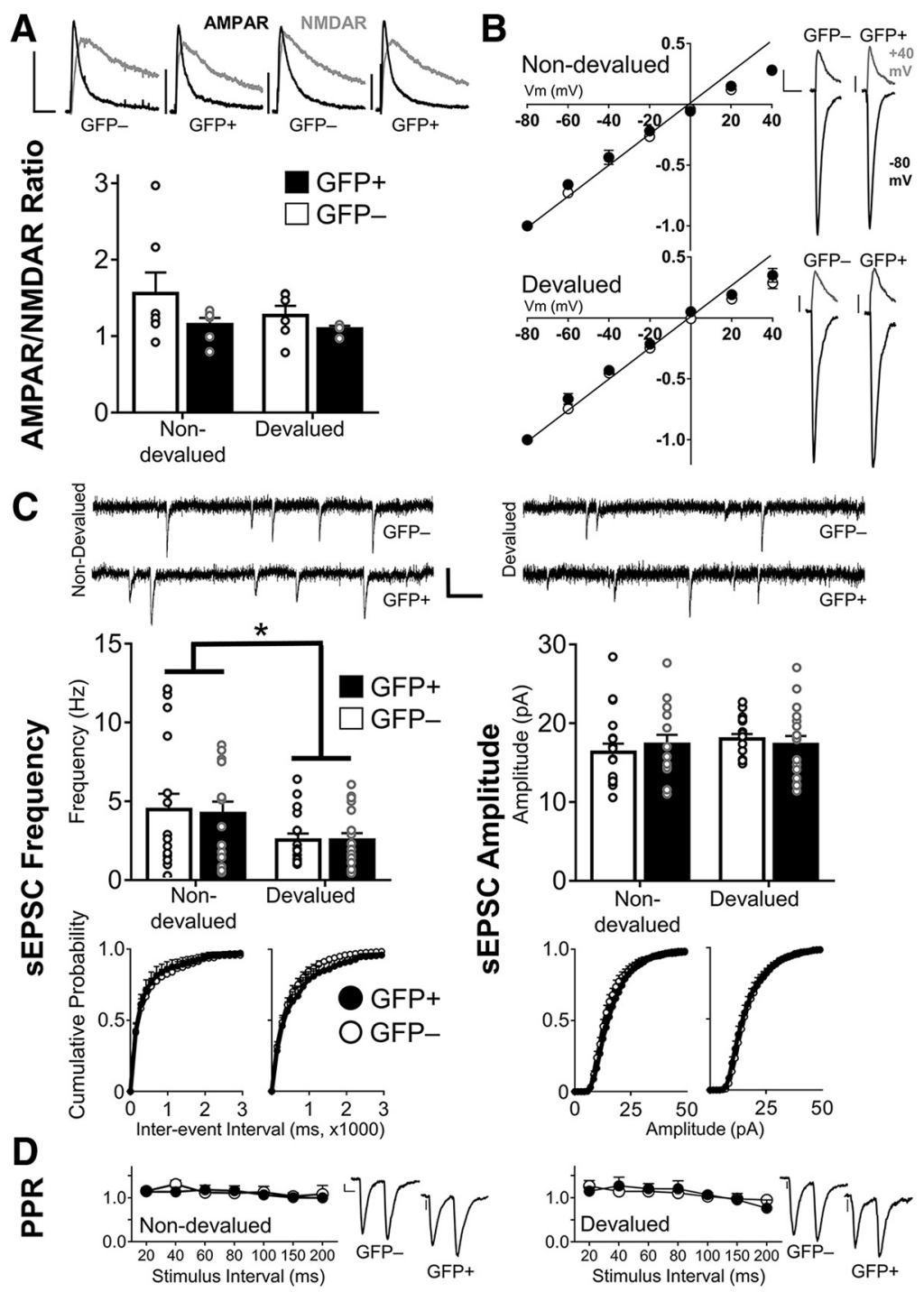

Figure 5. Devaluation did not modulate the synaptic strength of $\mathrm{GFP}^{+}$neurons. $\boldsymbol{A}_{\text {, AMPAR/NMDAR ratios between } \text { GFP }^{+} \text {and GFP }}$ a $^{-}$ neurons were similar in both the Non-devalued and Devalued groups (Non-devalued: GFP ${ }^{-}, 7 / 7 ;$ GFP $^{+}, 6 / 5$; Devalued: GFP ${ }^{-}$, 6/6; $\left.\mathrm{GFP}^{+}, 4 / 3\right)$. Top, Representative AMPAR/NMDAR traces from $\mathrm{GFP}^{+}$and GFP ${ }^{-}$neurons. Calibration: $50 \mathrm{pA}, 50 \mathrm{~ms}$. $\boldsymbol{B}, \mathrm{AMPAR}^{-}$ rectification was similar in activated ensembles following non-devaluation and devaluation (Non-devalued group: GFP ${ }^{-}=, 5 / 4 ; \mathrm{GFP}^{+}$, 4/4; Devalued group: $\mathrm{GFP}^{-}, 5 / 4$; $\mathrm{GFP}^{+}, 5 / 3$ ). The data shown are normalized to the current peak at $-80 \mathrm{mV}$. Right, Representative images of Non-devalued and Devalued rectification curves in $\mathrm{GFP}^{+}$and $\mathrm{GFP}^{-}$neurons at $+40 \mathrm{mV}$ (gray) and $-80 \mathrm{mV}$ (black). Calibration: 50 pA, 10 ms. C, Representative sEPSC traces from Non-devalued and Devalued mice. Calibration: 20 pA, 100 ms. sEPSC frequency (left) and amplitude (right) were not selectively modulated in GFP ${ }^{+}$and GFP $^{-}$neurons (Non-devalued: GFP ${ }^{-}, 19 / 8$; GFP $^{+}, 15 / 8$; Devalued: GFP ${ }^{-}, 17 / 6$; GFP $\left.{ }^{+}, 18 / 6\right)$. However, reward devaluation reduced sEPSC frequency nonselectively across both neuron types $(* p<0.05)$. $\boldsymbol{D}$, Paired-pulse ratios were similar in $\mathrm{GFP}^{+}$and $\mathrm{GFP}^{-}$neurons from Non-devalued and Devalued mice (Non-devalued: GFP ${ }^{-}, 13 / 10$; GFP ${ }^{+}, 8 / 8$; Devalued: GFP ${ }^{-}, 8 / 7$; GFP $^{+}, 5 / 4$ ). Calibration: 100 pA, 10 ms. Data are expressed as the mean \pm SEM; values to the right of $\mathrm{GFP}^{-}$and $\mathrm{GFP}^{+}$denote the number of cells recorded/number of mice used.

Figure Contributions: M.C.S. and J.J.Z. performed experiments; J.J.Z. analyzed the data.

circuit level, neuronal activation after devaluation may be reduced via inhibition from local interneurons that control ensemble size. Additionally, decreased excitatory drive from cortical afferents mediating goal-directed behaviors from areas such as the basolateral amygdala and ventral hippocampus may contribute (Taverna et al., 2005; Wilson, 2007; Shiflett and Balleine, 2010; Stefanelli et al., 2016; LeGates et al., 2018). The result is reduced output into areas such as the lateral hypothalamus and ventral tegmental area, and thus attenuation of cue-evoked sucrose seeking (Kelley et al., 2005; Castro et al., 2015; Yang et al., 2018).

NAc neurons expressing either the dopamine 1 receptor $\left(D_{1} R\right)$ or dopamine 2 receptor $\left(D_{2} R\right)$ project to different mesocorticolimbic structures and play distinct roles in reward-related behaviors (Smith et al., 2013). Here, we did not distinguish neurons based on their $D_{1} R / D_{2} R$ expression. It has recently been observed that conditioning and 
extinction learning do not modulate the proportion of $D_{1} R$ and $D_{2} R$-expressing ensembles following cue exposure (Ziminski et al., 2017). Also, there are no clear differences in goal-directed behavior on optogenetic stimulation of either subpopulation (Natsubori et al., 2017). Hence, it is likely that devaluation recruits an ensemble with similar levels of $D_{1} R$ - and $D_{2} R$-expressing neurons. However, additional investigations are necessary to confirm this.

\section{Implications for lack of ensemble excitability differences following devaluation}

Following reward-specific devaluation, the previous excitability differences observed between ensemble and non-ensemble neurons were eliminated. In vivo, such shifts in excitability may modulate neuronal firing in response to cue presentations. In support, devaluation reduces the number of phasically firing NAc neurons in response to sucrose cues (West and Carelli, 2016). But what is the identity of this ensemble activated following devaluation that does not differ in excitability from nonensemble neurons? After devaluation, we may have recorded from a smaller subset of the same ensemble that was activated under Non-devalued conditions during sucrose seeking, which may have updated the cue-reward association. Alternatively, others have reported that ensembles that promote and inhibit food seeking coexist in the same brain area (Suto et al., 2016; Warren et al., 2016). Therefore, after devaluation we may have recorded from a different and incidentally smaller ensemble, which represented the changed reward value. While distinguishing these two possibilities is challenging, future studies may longitudinally monitor cue-activated NAc neurons with and without devaluation and functionally interrogate them using optogenetics/chemogenetics to determine which of the above possibilities are relevant.

The elimination of excitability differences between ensemble and non-ensemble neurons following devaluation arose from a slight enhancement of excitability only in non-ensemble neurons. These excitability differences are thought to boost the signal-to-noise ratio of information processing of ensemble neurons (Nicola et al., 2000; Ziminski et al., 2018), and its elimination may thus attenuate the responsivity to food-associated cues following devaluation. The cause for this increased background excitability is unclear, but we note that sucrose consumption increases NAc shell dopamine transmission (Roitman et al., 2008). This dopamine release resulting from daily sucrose consumption may enhance MSN excitability through $D_{1} R$ activation (Hernández-López et al., 1997). Here, we did not observe any associated changes in active and passive membrane properties in these nonensemble neurons. This observed lack of change may have resulted from not distinguishing our NAc MSNs based on dopamine receptor expression, which may have masked any subtle cell-type specific changes. Finally, enhancements in firing capacity have been observed following $D_{1} R$ activation without any changes in Ri, spike threshold, and duration (Tseng and O'Donnell, 2004), de- spite the known role of $D_{1} R$ activation enhancing L-type $\mathrm{Ca}^{+2}$ currents that regulate repetitive firing (HernándezLópez et al., 1997). This indicates that subtle changes in passive and active membrane properties may not always be detected despite alterations in firing capacity. Further studies are required to parse out the cellular and intrinsic factors that resulted in this minor, but widespread enhancement in neuronal firing following devaluation.

\section{Potential reasons for lack of learning- or devaluation-induced ensemble-specific differences in synaptic physiology}

Surprisingly, despite the role of glutamate synapse alterations in appetitive learning, we found no alterations in sEPSC frequency and amplitude, AMPAR/NMDAR current ratio, AMPA rectification index, and PPR. We, however, observed a generalized reduction in SEPSC frequency, indicating synaptic alterations induced by ad libitum sucrose consumption. This contrasts with studies using drug rewards demonstrating increased spine dynamics in NAc ensembles selectively activated in response to drugassociated cues (Singer et al., 2016; Whitaker et al., 2016). This difference between natural and drug rewards in their ability to generate synaptic alterations in NAc may be due to natural rewards being less potent at eliciting behavioral and neurophysiological changes (Grimm et al., 2003; Chen et al., 2008; Gipson et al., 2013). Additionally, for associative learning paradigms using natural reinforcers, an extended time frame or paradigms with more CS-US pairings may be needed to induce synaptic alterations (Cifani et al., 2012; Guegan et al., 2013a,b; Counotte et al., 2014). Together, the lack of indices of plasticity at glutamatergic synapses demonstrate neuronal ensembles in NAc that may reflect inherent differences of natural and drug rewards and the way their behavioral outcomes are manifested.

\section{The role of ensemble changes in intrinsic excitability, but not synaptic physiology}

Few studies to date have examined the role of both intrinsic and synaptic plasticity in appetitive associative learning. So far, fear conditioning studies have demonstrated the concomitant alterations of intrinsic excitability and synaptic physiology following associative learning (Rosenkranz and Grace, 2002). In contrast, we found neuronal excitability, but not excitatory synaptic physiology, to be altered by devaluation. In line with our findings, previous studies have reported excitability changes independently of synaptic plasticity (Egorov et al., 2002; Labno et al., 2014). It is proposed that alterations in excitability may serve as a transient priming mechanism for initial associative memory formation before synaptic changes take place (Moyer et al., 1996; Janowitz and Van Rossum, 2006; Mozzachiodi and Byrne, 2010). Further research is needed to determine whether our observed excitability changes constitute a transient priming mechanism active during rule learning of the updated reward value and whether synaptic alterations consolidating this updated value might be detectable later on. 


\section{Limitations and conclusion}

Reward-specific devaluation, but not caloric satiation, attenuated cue-evoked sucrose seeking. Thus, it is conceivable that the associated effects on Fos expression and ensemble excitability are due to a decreased value of sucrose reward. However, the present study cannot rule out the possibility that our observed Fos and excitability alterations were modulated by caloric satiety provided during sucrose devaluation. Therefore, although caloric satiation alone did not attenuate sucrose seeking, it would be critical in future studies to determine whether caloric satiation attenuates Fos expression and eliminates excitability differences between ensemble and non-ensemble neurons in the absence of CS exposure.

Fos expression requires sustained neuronal activity and therefore only labels strongly activated neurons, which play a role in cue-evoked behaviors (Koya et al., 2009; Cruz et al., 2013; Warren et al., 2016; Whitaker et al., 2016). In Fos-GFP rats and mice, GFP is coexpressed with Fos and peaks $2 \mathrm{~h}$ after induction and is back to baseline by 24 h (Barth, 2004; Cifani et al., 2012; Koya et al., 2012). Hence, it is unlikely that many of the GFP ${ }^{+}$ neurons in the current study were activated long before the Pavlovian approach test, although $\mathrm{GFP}^{+}$neurons might have been activated by other events close in time. Thus, in our Devalued group, recent sucrose consumption may have induced Fos (Sheng and Greenberg, 1990; Cruz et al., 2015). However, Fos induction in the striatum habituates rapidly, and the consumption of a sweet solution has been shown to not alter Fos expression in NAc (Duncan et al., 1996; Struthers et al., 2005). Hence, our GFP ${ }^{+}$ neurons likely represent neurons activated during Pavlovian approach testing rather than recent sucrose consumption. However, to establish this possibility we would need to use strategies that would label neurons activated by both recent sucrose consumption and CS exposure. Activity-sensitive immediate early genes homer1a and arc may be useful for such studies as they are used to label neurons activated by distinct stimuli presented at two different time points (Grosso et al., 2015).

Differences in Fos induction based on satiety state have been observed previously. Ad libitum chowmaintained rats exhibited no change in NAc Fos protein or mRNA on consumption of a sweet solution or pellets (Duncan et al., 1996; Gao et al., 2017). However, when mice are food restricted, palatable food consumption has been shown to increase Fos expression in NAc (Latagliata et al., 2018). In the current study, we did not see this satiety-based increase in Fos, as after $4 \mathrm{~d}$ of sucrose consumption the effects of reward devaluation on Fos expression may outweigh the satiety effects of sucrose consumption, resulting in the observed decrease in Fos levels. To shed light on this, future studies could investigate Fos levels after shorter periods of sucrose consumption.

In this study, all of our mice were trained under "Paired" conditions in which CS and US presentations occurred in temporal proximity. We did not use an "Unpaired" control group that receives CS and US presentations at disparate times (e.g., CS in the conditioning chamber, US in the home cage) to prevent their association. This control group is used to parse out neuronal activation and excitability patterns that are induced by general stimuli that are not explicitly paired with the US. We observed enhanced excitability in CS-activated neurons in our Non-devalued control group. Ziminski et al. (2017) demonstrated in FosGFP mice that sucrose-associated CSs increased GFP expression by 1.4-fold and recruited a hyperexcitable $\mathrm{GFP}^{+}$ensemble in the Paired group compared with the Unpaired group. These additional $\mathrm{GFP}^{+}$neurons likely represent those that are recruited by sucrose cue exposure. Thus, the ensemble hyperexcitability in the Nondevalued control group occurred as a result of the CS being paired with sucrose and is not a general property of activated neurons. Interestingly, Fos expression decreased by 1.4-fold following devaluation (Fig. 2B), which suggests that devaluation reduced Fos expression related to sucrose cue exposure. However, it remains to be determined whether ad libitum sucrose consumption alone is capable of attenuating Fos expression in Unpaired mice.

As Devalued mice made fewer head entries during the $\mathrm{CS}$, they may have experienced a reduced amount of extinction learning compared with Non-devalued mice. These differences in extinction learning may have elicited devaluation-independent consequences on NAc activation patterns and hence decreased Fos expression. However, Ziminski et al. (2017) demonstrated that extinction learning decreased NAc Fos expression. As Non-devalued mice with more opportunity for extinction learning expressed more Fos than Devalued mice, this reduction is unlikely due to the reduced opportunity to engage in extinction learning in Devalued mice.

Here we revealed that devaluation was associated with altered ensemble size and intrinsic excitability, but not synaptic plasticity in behaviorally activated neuronal ensembles in the NAc shell. Our findings reveal novel mechanisms underlying cognitive and behavioral flexibility. However, future studies are required to elucidate the functional role of devaluation-activated neuronal ensembles. For instance, chemogenetic or optogenetic approaches using Fos-tTA mice that allow tagging and stimulation of Fos-expressing neurons will allow us to reveal whether activation of Fos-expressing neurons following devaluation is sufficient to reduce cue-evoked sucrose seeking (Cruz et al., 2013). Additionally, we need to identify the afferent brain areas that regulate these forms of ensemble plasticity and the downstream areas that are modulated as a result to further elucidate mechanisms that suppress food seeking. Such processes are important to understand why certain individuals are hypersensitive to food cues and resistant to internal signals that help limit food intake. 
Table 2: Summary of statistical analyses

\begin{tabular}{|c|c|c|c|c|c|c|c|}
\hline \multirow{6}{*}{$\begin{array}{l}\text { Check for } \\
\text { pre-existing } \\
\text { differences in } \\
\text { acquisition } \\
\text { of Pavlovian } \\
\text { conditioning } \\
\text { between } \\
\text { (future) } \\
\text { groups: } \\
\text { Devalued vs } \\
\text { Non-devalued } \\
\text { and ad libitum } \\
\text { chow vs control }\end{array}$} & \multirow{6}{*}{\begin{tabular}{l}
\multicolumn{1}{c}{ Data structure } \\
Quantification of \\
head entries \\
during acquisition \\
of Pavlovian \\
conditioning \\
during CS \\
and ITI, \\
displayed as \\
difference \\
score
\end{tabular}} & \multirow{6}{*}{$\begin{array}{l}\text { Type of test } \\
\text { Two-way } \\
\text { mixed } \\
\text { ANOVAs }\end{array}$} & \multicolumn{5}{|c|}{$95 \%$ Confidence interval } \\
\hline & & & Session & 1 & 2 & 3 & 4 \\
\hline & & & Non-devalued & $0.14-0.02$ & $0.0069-0.16$ & $0.18-0.30$ & $0.15-0.33$ \\
\hline & & & Devalued & $-0.25-0.055$ & $0.014-0.29$ & $0.13-0.27$ & $0.033-0.25$ \\
\hline & & & Control & $-0.28-0.059$ & $-0.0060-0.21$ & $0.057-0.26$ & $0.0019-0.22$ \\
\hline & & & Ad libitum chow & $-0.066-0.088$ & $0.030-0.19$ & $0.22-0.34$ & $0.044-0.28$ \\
\hline \multirow{3}{*}{$\begin{array}{l}\text { Acquisition of } \\
\text { Pavlovian } \\
\text { conditioning } \\
\text { (Fig. 1B) }\end{array}$} & \multirow{3}{*}{$\begin{array}{l}\text { Quantification } \\
\text { of head } \\
\text { entries during } \\
\text { acquisition } \\
\text { of Pavlovian } \\
\text { conditioning } \\
\text { during CS } \\
\text { and ITI }\end{array}$} & Two-way & Session & 1 & 2 & 3 & 4 \\
\hline & & repeated & cs & $41.34-56.04$ & $62.12-74.76$ & $58.39-72.25$ & $48.13-62.31$ \\
\hline & & $\begin{array}{l}\text { measures } \\
\text { ANOVA }\end{array}$ & ITI & $46.08-56.86$ & $50.13-61.81$ & $37.22-48.16$ & $31.68-39.76$ \\
\hline \multirow{5}{*}{$\begin{array}{l}\text { Pavlovian } \\
\text { approach } \\
\text { test (Fig. 1C,E) }\end{array}$} & \multirow{5}{*}{$\begin{array}{l}\text { Quantification } \\
\text { of head } \\
\text { entries } \\
\text { during } \\
\text { Pavlovian } \\
\text { approach } \\
\text { test during } \\
\text { CS and ITI } \\
\text { in Devalued } \\
\text { vs Non-devalued } \\
\text { and ad libitum } \\
\text { chow vs } \\
\text { control groups }\end{array}$} & \multirow{5}{*}{$\begin{array}{l}\text { Two-way } \\
\text { mixed } \\
\text { ANOVAs }\end{array}$} & & & & CS & \\
\hline & & & Non-devalued & & & $12.28-20.60$ & \\
\hline & & & Devalued & & & $8.61-13.11$ & \\
\hline & & & Control & & & $13.68-19.74$ & \\
\hline & & & Ad libitum chow & & & $9.90-21.26$ & \\
\hline \multirow{4}{*}{$\begin{array}{l}\text { Body } \\
\text { weights } \\
\text { (Fig. 1D,F) }\end{array}$} & \multirow{4}{*}{$\begin{array}{l}\text { Body weights } \\
\text { normalized } \\
\text { to free } \\
\text { feeding body } \\
\text { weight in } \\
\text { Devalued vs } \\
\text { Non-devalued and } \\
\text { ad libitum } \\
\text { chow vs } \\
\text { control } \\
\text { groups }\end{array}$} & \multirow{4}{*}{$\begin{array}{l}\text { Unpaired } \\
\text { two-tailed } \\
\text { t-tests }\end{array}$} & Non-devalued & & & & \\
\hline & & & Devalued & & & & \\
\hline & & & Control & & & & \\
\hline & & & Ad libitum chow & & & & \\
\hline $\begin{array}{l}\text { Fos quantification } \\
\text { (Fig. 2B) }\end{array}$ & $\begin{array}{l}\text { Quantification } \\
\text { of Fos }{ }^{+} \\
\text {celll in } \\
\text { NAc shell } \\
\text { in Devalued } \\
\text { and Non-devalued } \\
\text { groups; } \\
\text { two images } \\
\text { were taken } \\
\text { per hemisphere } \\
\text { (dorsal and } \\
\text { ventral) and } \\
\text { numbers of } \\
\text { Fos }{ }^{+} \text {neurons } \\
\text { were } \\
\text { added to get } \\
\text { one value per } \\
\text { hemisphere, } \\
\text { between } \\
\text { hemispheres } \\
\text { values were } \\
\text { averaged to } \\
\text { get one } \\
\text { value per } \\
\text { mouse }\end{array}$ & $\begin{array}{l}\text { Two-tailed } t \\
\text { test }\end{array}$ & $\begin{array}{l}\text { Non-devalued } \\
\text { Devalued }\end{array}$ & & & & \\
\hline \multirow{5}{*}{$\begin{array}{l}\text { Excitability } \\
\text { data } \\
\text { (Fig. } 3 C-F)\end{array}$} & \multirow{5}{*}{$\begin{array}{l}\text { Quantification } \\
\text { of action } \\
\text { potentials } \\
\text { after } \\
\text { injection } \\
\text { of increasing } \\
\text { current steps } \\
(20-116 \mathrm{pA}) \text { in } \\
\mathrm{GFP}^{+} \text {and } \\
\text { GFP }^{-} \\
\text {neurons in } \\
\text { Devalued and } \\
\text { Non-devalued } \\
\text { groups }\end{array}$} & \multirow{5}{*}{$\begin{array}{l}\text { Three-way } \\
\text { mixed } \\
\text { ANOVAs, } \\
\text { two-way } \\
\text { mixed } \\
\text { ANOVAs }\end{array}$} & & $\begin{array}{l}\text { Current } \\
\text { step }(p A)\end{array}$ & 20 & 32 & 44 \\
\hline & & & Non-devalued & $\mathrm{GFP}^{-}$ & $0.0-0.0$ & $0.0-0.0$ & $0.0-0.0$ \\
\hline & & & 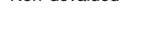 & $\mathrm{GFP}^{+}$ & $0.0-0.0$ & $0.0-0.0$ & $0.0-0.0$ \\
\hline & & & Devalued & $\mathrm{GFP}^{-}$ & $0.0-0.0$ & $0.0-0.0$ & $0.0-0.0$ \\
\hline & & & & $\mathrm{GFP}^{+}$ & $0.0-0.0$ & $0.0-0.0$ & $0.0-0.0$ \\
\hline (Continued) & & & & & & & \\
\hline
\end{tabular}


Table 2: Summary of statistical analyses (Continued)

\begin{tabular}{|c|c|c|c|c|c|c|c|}
\hline 5 & 6 & 7 & 8 & 9 & 10 & 11 & 12 \\
\hline $0.24-0.40$ & $0.28-0.40$ & $0.19-0.35$ & $0.21-0.35$ & $0.22-0.38$ & $0.29-0.41$ & $0.34-0.44$ & $0.30-0.46$ \\
\hline $0.25-0.39$ & $0.29-0.45$ & $0.18-0.32$ & $0.17-0.35$ & $0.21-0.39$ & $0.31-0.49$ & $0.41-0.51$ & $0.25-0.41$ \\
\hline $0.074-0.25$ & $0.053-0.27$ & $0.14-0.38$ & $0.18-0.40$ & $0.24-0.32$ & $0.13-0.25$ & $0.21-0.35$ & $0.23-0.37$ \\
\hline $0.11-0.25$ & $0.20-0.34$ & $0.16-0.34$ & $0.18-0.34$ & $0.19-0.33$ & $0.17-0.35$ & $0.23-0.35$ & $0.11-0.35 a$ \\
\hline 5 & 6 & 7 & 8 & 9 & 10 & 11 & $12 \mathrm{a}$ \\
\hline $53.28-64.16$ & $49.29-61.15$ & $55.64-66.48$ & $50.85-62.33$ & $65.36-76.70$ & $59.76-71.30$ & $53.28-67.84$ & $49.93-59.59$ \\
\hline $27.73-34.59$ & $23.32-30.24$ & $29.49-37.29$ & $28.78-35.60$ & $33.18-44.58$ & $25.32-32.56$ & $20.90-27.16$ & $22.41-29.53$ \\
\hline
\end{tabular}

ITI

$6.35-11.27$ $5.20-8.80$ 8.73-15.27 6.84-11.50

\section{$0.91-0.93$} $0.99-1.01$

0.89-0.91

$1.01-1.05$

$58.01-98.83$

39.83-64.97
56
$0.0-0.0$

$-0.21-0.87$

$-0.15-0.37$ 68

$0.0-0.0$

$-0.71-3.51$

$-0.59-8.19$
80

0.0-0.0

$5.25-13.65$

1.07-8.93

$-0.66-11.46$ 
Table 2: Continued

\begin{tabular}{|c|c|c|c|c|c|c|c|c|c|c|}
\hline \multirow{6}{*}{$\begin{array}{l}I-V \text { curves } \\
\text { (inlays Fig. } 3 C-F \text { ) }\end{array}$} & \multirow{6}{*}{$\begin{array}{l}\text { Data structure } \\
\text { Voltage } \\
\text { displacement } \\
\text { (mV) to } \\
\text { subthreshold } \\
\text { current } \\
\text { injections in } \\
\text { the range } \\
\text { of }(-60 \text { to } \\
-20 \mathrm{pA}) \\
\text { in GFP } \\
\text { and GFP } \\
\text { neurons in } \\
\text { Devalued and } \\
\text { Non-devalued } \\
\text { groups }\end{array}$} & \multirow{6}{*}{$\begin{array}{l}\text { Type of test } \\
\text { Three-way } \\
\text { mixed } \\
\text { ANOVAs, } \\
\text { Two-way } \\
\text { mixed } \\
\text { ANOVAs }\end{array}$} & \multicolumn{8}{|c|}{ 95\% Confidence interval } \\
\hline & & & & & -60 & -56 & -52 & -48 & -44 & -40 \\
\hline & & & Non-devalued & $\mathrm{GFP}^{-}$ & -8.59 to -4.92 & -8.39 to -6.02 & -7.82 to 5.62 & -7.52 to -5.35 & -7.01 to -5.04 & -6.40 to -4.50 \\
\hline & & & & $\mathrm{GFP}^{+}$ & -13.6 to -9.3 & -13.6 to -8.8 & -12.4 to -8.1 & -11.7 to -7.6 & -11.0 to -7.1 & -9.9 to -6.4 \\
\hline & & & Devalued & $\mathrm{GFP}^{-}$ & -8.45 to -6.88 & -7.90 to -6.31 & -7.48 to -5.97 & -7.78 to -5.85 & -7.31 to -5.37 & -6.46 to -4.73 \\
\hline & & & & $\mathrm{GFP}^{+}$ & -11.510 to -8.13 & -11.75 to -7.70 & -11.056 to -7.33 & -1.005 to -7.058 & -9.102 to -6.49 & -8.09 to -5.73 \\
\hline \multirow{24}{*}{$\begin{array}{l}\text { Membrane } \\
\text { and AP } \\
\text { parameters } \\
\text { (Fig. } 4 A-F, \text { Table 1) }\end{array}$} & \multirow{24}{*}{$\begin{array}{l}\text { RMP, input } \\
\text { resistance, } \\
\text { AHP, AP } \\
\text { amplitude and } \\
\text { half-width, } \\
\text { Rheobase in } \\
\text { GFP }^{+} \text {and GFP } \\
\text { neurons } \\
\text { in Devalued } \\
\text { and Non- } \\
\text { devalued } \\
\text { groups }\end{array}$} & \multirow{24}{*}{$\begin{array}{l}\text { Two-way } \\
\text { ANOVAs }\end{array}$} & \multirow[t]{4}{*}{ RMP } & \multirow[t]{2}{*}{ Non-devalued } & $\mathrm{GFP}^{-}$ & & & -72.30 to -69.30 & & \\
\hline & & & & & $\mathrm{GFP}^{+}$ & & & -71.82 to -66.90 & & \\
\hline & & & & \multirow[t]{2}{*}{ Devalued } & GFP $^{-}$ & & & -70.88 to -67.30 & & \\
\hline & & & & & $\mathrm{GFP}^{+}$ & & & -72.15 to -68.45 & & \\
\hline & & & \multirow[t]{4}{*}{ Input resistance } & \multirow[t]{2}{*}{ Non-devalued } & GFP $^{-}$ & & & $127.02-175.28$ & & \\
\hline & & & & & $\mathrm{GFP}^{+}$ & & & $185.04-308.02$ & & \\
\hline & & & & \multirow[t]{2}{*}{ Devalued } & $\mathrm{GFP}^{-}$ & & & $131.78-170.12$ & & \\
\hline & & & & & $\mathrm{GFP}^{+}$ & & & $161.81-239.41$ & & \\
\hline & & & \multirow[t]{4}{*}{ AHP } & \multirow[t]{2}{*}{ Non-devalued } & $\mathrm{GFP}^{-}$ & & & -10.02 to -7.82 & & \\
\hline & & & & & $\mathrm{GFP}^{+}$ & & & -11.49 to -8.09 & & \\
\hline & & & & \multirow{2}{*}{ Devalued } & GFP $^{-}$ & & & -9.60 to -5.88 & & \\
\hline & & & & & $\mathrm{GFP}^{+}$ & & & -9.18 to -5.38 & & \\
\hline & & & \multirow{4}{*}{ AP amplitude } & \multirow{2}{*}{ Non-devalued } & $\mathrm{GFP}^{-}$ & & & $67.83-72.03$ & & \\
\hline & & & & & $\mathrm{GFP}^{+}$ & & & 49.43-67.99 & & \\
\hline & & & & \multirow[t]{2}{*}{ Devalued } & GFP $^{-}$ & & & $58.67-73.17$ & & \\
\hline & & & & & $\mathrm{GFP}^{+}$ & & & $54.98-72.08$ & & \\
\hline & & & \multirow[t]{4}{*}{ AP half-width } & Non-devalued & $\mathrm{GFP}^{-}$ & & & $1.17-1.61$ & & \\
\hline & & & & & $\mathrm{GFP}^{+}$ & & & $1.42-1.94$ & & \\
\hline & & & & Devalued & GFP $^{-}$ & & & $1.29-1.43$ & & \\
\hline & & & & & $\mathrm{GFP}^{+}$ & & & $1.35-1.51$ & & \\
\hline & & & Rheobase & Non-devalued & GFP $^{-}$ & & & $91.26-138.74$ & & \\
\hline & & & & & $\mathrm{GFP}^{+}$ & & & $54.17-72.23$ & & \\
\hline & & & & Devalued & $\mathrm{GFP}^{-}$ & & & $61.02-120.98$ & & \\
\hline & & & & & $\mathrm{GFP}^{+}$ & & & $64.20-118.20$ & & \\
\hline AMPAR/ & Ratios of & Two-way & Non-devalued & & GFP $^{-}$ & & & $0.88-2.24$ & & \\
\hline NMDAR & AMPAR to & ANOVAs & & & $\mathrm{GFP}^{+}$ & & & $0.93-1.37$ & & \\
\hline $\begin{array}{l}\text { current } \\
\text { ratio (Fig. 5A) }\end{array}$ & NMDAR & & Devalued & & GFP $^{-}$ & & & $0.95-1.59$ & & \\
\hline & $\begin{array}{l}\text { (recorded } \\
\text { at }+40 \mathrm{mV} \text { ) } \\
\text { in } \mathrm{GFP}^{+} \\
\text {and } \mathrm{GFP}^{-} \\
\text {neurons } \\
\text { in Devalued } \\
\text { and Non- } \\
\text { devalued } \\
\text { groups }\end{array}$ & & & & $\mathrm{GFP}^{+}$ & & & $0.95-1.23$ & & \\
\hline AMPAR & Absolute ratios & Two-way & Non-devalued & & $\mathrm{GFP}^{-}$ & & & $2.91-4.43$ & & \\
\hline rectification & of AMAR & ANOVA & & & $\mathrm{GFP}^{+}$ & & & $3.11-3.97$ & & \\
\hline index & EPSC recorded & & Devalued & & GFP $^{-}$ & & & $1.88-5.98$ & & \\
\hline & $\begin{array}{l}\text { at }-80 \mathrm{mV} \text { to the } \\
\text { at }+40 \mathrm{mV} \text { in } \\
\text { GFP }^{+} \text {and } \mathrm{GFP}^{-} \\
\text {neurons in } \\
\text { Devalued and } \\
\text { Non-devalued } \\
\text { groups }\end{array}$ & & & & $\mathrm{GFP}^{+}$ & & & $1.65-4.73$ & & \\
\hline Chord & Chord & & Non-devalued & & $\mathrm{GFP}^{-}$ & & & $0.44-0.68$ & & \\
\hline conductance & conductance & & & & GFP $^{+}$ & & & $0.50-0.64$ & & \\
\hline ratios & $(\mathrm{G}=1-V)$ & & Devalued & & $\mathrm{GFP}^{-}$ & & & $0.32-0.84$ & & \\
\hline & $\begin{array}{l}\text { at }+40 \mathrm{mV} \\
\text { was divided } \\
\text { by the chord } \\
\text { conductance } \\
\text { at }-80 \mathrm{mV} \\
\text { in } \mathrm{GFP}^{+} \text {and } \\
\mathrm{GFP}^{-} \text {neurons } \\
\text { in Devalued } \\
\text { and Non-devalued } \\
\text { groups }\end{array}$ & & & & $\mathrm{GFP}^{+}$ & & & $0.39-1.01$ & & \\
\hline sEPSC & Number of & Two-way & Non-devalued & & $\mathrm{GFP}^{-}$ & & & $2.37-6.59$ & & \\
\hline frequency & sEPSCs over & ANOVA & & & $\mathrm{GFP}^{+}$ & & & $2.63-5.83$ & & \\
\hline (Fig. 5C) & $\begin{array}{l}\text { a } 30 \mathrm{~s} \text { period } \\
\text { expressed }\end{array}$ & & Devalued & & GFP $^{-}$ & & & $1.66-3.42$ & & \\
\hline & $\begin{array}{l}\text { expressed } \\
\text { in Hz in GFP } \\
\text { and GFP } \\
\text { neurons in } \\
\text { Devalued and } \\
\text { Non-devalued } \\
\text { groups }\end{array}$ & & & & $\mathrm{GFP}^{+}$ & & & $1.60-3.48$ & & \\
\hline (Continued) & & & & & & & & & & \\
\hline
\end{tabular}


Table 2: Summary of statistical analyses (Continued)

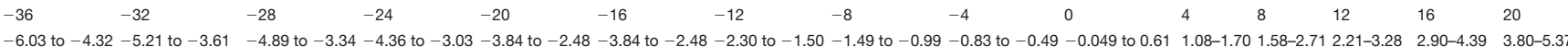

-6.03 to $-4.32-5.21$ to $-3.61-4.89$ to $-3.34-4.36$ to $-3.03-3.84$ to $-2.48-3.84$ to $-2.48-2.30$ to $-1.50-1.49$ to $-0.99-0.83$ to $-0.49-0.049$ to $0.61 \quad 1.08-1.701 .58-2.712 .21-3.282 .90-4.39 \quad 3.80-5.37$
-9.60 to $-6.14-8.47$ to $-5.32-7.47$ to $-4.80-6.95$ to $-4.17-6.13$ to $-3.47-5.18$ to $-2.95-4.11$ to $-2.37-2.73$ to $-1.49-1.80$ to $-0.40-0.30$ to $-1.181 .11-2.131 .89-4.023 .004-4.563 .61-6.264 .95-10.081$

-5.70 to $-4.54-5.69$ to $-3.96-4.60$ to $-3.54-4.10$ to $-3.19-3.56$ to $-2.85-2.73$ to $-2.08-2.81$ to $-1.82-1.42$ to $-0.99-1.18$ to $-0.22-0.32$ to $0.70 \quad 0.88-1.921 .96-2.532 .46-4.092 .66-4.09 \quad 3.66-5.12$

-8.28 to $-5.59-7.088$ to $-4.76-6.53$ to $-4.28-5.29$ to $-3.53-4.52$ to $-3.18-4.25$ to $-2.67-3.18$ to $-2.12-1.72$ to $-1.21-1.056$ to $0.46-0.16$ to $1.10 \quad 1.07-1.751 .87-3.522 .71-4.50 \quad 3.79-5.54 \quad 4.90-7.73$ 
Table 2: Continued

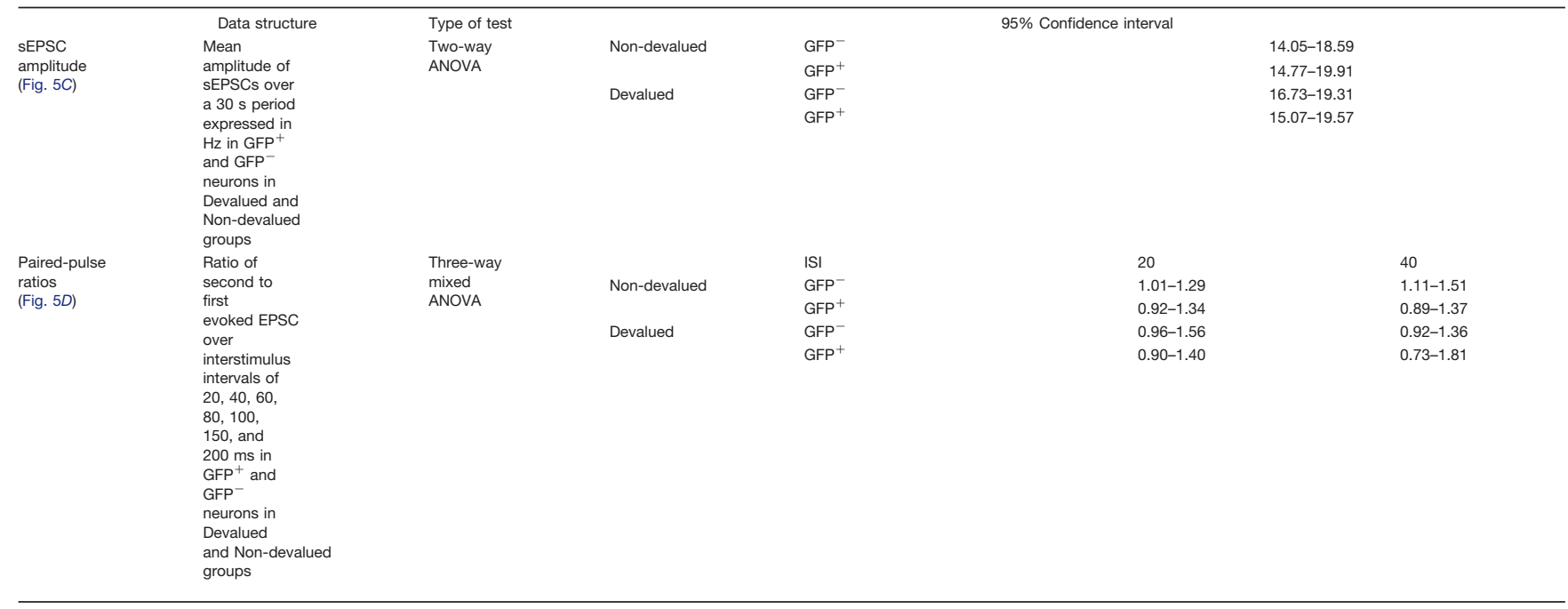

\section{References}

Barth AL (2004) Alteration of neuronal firing properties after in vivo experience in a FosGFP transgenic mouse. J Neurosci 24:64666475.

Baxter MG, Parker A, Lindner CC, Izquierdo AD, Murray EA (2000) Control of response selection by reinforcer value requires interaction of amygdala and orbital prefrontal cortex. J Neurosci 20:43114319.

Berridge K, Grill HJ, Norgren R (1981) Relation of consummatory responses and preabsorptive insulin release to palatability and learned taste aversions. J Comp Physiol Psychol 95:363-382.

Boswell RG, Kober H (2016) Food cue reactivity and craving predict eating and weight gain: a meta-analytic review. Obes Rev 17:159177.

Cacciapaglia F, Saddoris MP, Wightman RM, Carelli RM (2012) Differential dopamine release dynamics in the nucleus accumbens core and shell track distinct aspects of goal-directed behavior for sucrose. Neuropharmacology 62:2050-2056.

Carelli RM, ljames SG, Crumling AJ (2000) Evidence that separate neural circuits in the nucleus accumbens encode cocaine versus "natural" (water and food) reward. J Neurosci 20:4255-4266.

Castro DC, Cole SL, Berridge KC (2015) Lateral hypothalamus, nucleus accumbens, and ventral pallidum roles in eating and hunger: interactions between homeostatic and reward circuitry. Front Syst Neurosci 9:90.

Chen BT, Bowers MS, Martin M, Hopf FW, Guillory AM, Carelli RM, Chou JK, Bonci A (2008) Cocaine but not natural reward selfadministration nor passive cocaine infusion produces persistent LTP in the VTA. Neuron 59:288-297.

Cifani C, Koya E, Navarre BM, Calu DJ, Baumann MH, Marchant NJ, Liu QR, Khuc T, Pickel J, Lupica CR, Shaham Y, Hope BT (2012) Medial prefrontal cortex neuronal activation and synaptic alterations after stress-induced reinstatement of palatable food seeking: a study using c-fos-GFP transgenic female rats. J Neurosci 32: 8480-8490.

Counotte DS, Schiefer C, Shaham Y, O'Donnell P (2014) Timedependent decreases in nucleus accumbens AMPA/NMDA ratio and incubation of sucrose craving in adolescent and adult rats. Psychopharmacology (Berl) 231:1675-1684.

Cruz FC, Koya E, Guez-Barber DH, Bossert JM, Lupica CR, Shaham Y, Hope BT (2013) New technologies for examining the role of neuronal ensembles in drug addiction and fear. Nat Rev Neurosci 14:743-754.

Cruz FC, Javier Rubio F, Hope BT (2015) Using c-fos to study neuronal ensembles in corticostriatal circuitry of addiction. Brain Res 1628:157-173.
Cull-Candy S, Kelly L, Farrant M (2006) Regulation of Ca2+permeable AMPA receptors: synaptic plasticity and beyond. Curr Opin Neurobiol 16:288-297.

Day JJ, Carelli RM (2007) The nucleus accumbens and pavlovian reward learning. Neuroscientist 13:148-159.

Duncan GE, Knapp DJ, Breese GR (1996) Neuroanatomical characterization of Fos induction in rat behavioral models of anxiety. Brain Res 713:79-91.

Egorov AV, Hamam BN, Fransén E, Hasselmo ME, Alonso AA (2002) Graded persistent activity in entorhinal cortex neurons. Nature 420:173-178.

Gao P, Limpens JHW, Spijker S, Vanderschuren LJMJ, Voorn P (2017) Stable immediate early gene expression patterns in medial prefrontal cortex and striatum after long-term cocaine selfadministration. Addict Biol 22:354-368.

Gipson CD, Kupchik YM, Shen H, Reissner KJ, Thomas CA, Kalivas PW (2013) Relapse induced by cues predicting cocaine depends on rapid, transient synaptic potentiation. Neuron 77:867-872.

Goldstone AP, Prechtl de Hernandez CG, Beaver JD, Muhammed K, Croese C, Bell G, Durighel G, Hughes E, Waldman AD, Frost G, Bell JD (2009) Fasting biases brain reward systems towards highcalorie foods. Eur J Neurosci 30:1625-1635.

Grimm JW, Lu L, Hayashi T, Hope BT, Su T-P, Shaham Y (2003) Time-dependent increases in brain-derived neurotrophic factor protein levels within the mesolimbic dopamine system after withdrawal from cocaine: implications for incubation of cocaine craving. J Neurosci 23:742-747.

Grosso A, Cambiaghi M, Renna A, Milano L, Roberto Merlo G, Sacco T, Sacchetti B (2015) The higher order auditory cortex is involved in the assignment of affective value to sensory stimuli. Nat Commun 6:8886.

Guegan T, Cutando L, Ayuso E, Santini E, Fisone G, Bosch F, Martinez A, Valjent E, Maldonado R, Martin M (2013a) Operant behavior to obtain palatable food modifies neuronal plasticity in the brain reward circuit. Eur Neuropsychopharmacol 23:146-159.

Guegan T, Cutando L, Gangarossa G, Santini E, Fisone G, Martinez A, Valjent E, Maldonado R, Martin M (2013b) Operant behavior to obtain palatable food modifies ERK activity in the brain reward circuit. Eur Neuropsychopharmacol 23:240-252.

Guzman SJ, Schlögl A, Schmidt-Hieber C (2014) Stimfit: quantifying electrophysiological data with Python. Front Neuroinform 8:16.

Hernández-López S, Bargas J, Surmeier DJ, Reyes A, Galarraga E (1997) $D_{1}$ receptor activation enhances evoked discharge in neostriatal medium spiny neurons by modulating an L-type $\mathrm{Ca}^{2+}$ conductance. J Neurosci17:3334-3342. 


$\begin{array}{lll}60 & 80 & 100 \\ 0.96-1.28 & 0.86-1.34 & 0.83-1.41 \\ 0.94-1.42 & 0.90-1.42 & 0.93-1.19 \\ 0.93-1.35 & 0.93-1.29 & 0.84-1.22 \\ 0.88-1.52 & 0.70-1.70 & 0.93-1.19\end{array}$

$\begin{array}{ll}150 & 200 \\ 0.86-1.20 & 0.65-1.51 \\ 0.89-1.11 & 0.90-1.10 \\ 0.88-1.06 & 0.84-1.06 \\ 0.56-1.34 & 0.25-1.27\end{array}$

Holland PC, Rescorla RA (1975) The effect of two ways of devaluing the unconditioned stimulus after first- and second-order appetitive conditioning. J Exp Psychol Anim Behav Process 1:355-363.

Janowitz MK, Van Rossum MCW (2006) Excitability changes that complement Hebbian learning. Network 17:31-41.

Jansen A, Schyns G, Bongers P, van den Akker K (2016) From lab to clinic: extinction of cued cravings to reduce overeating. Physiol Behav 162:174-180.

Johnson AW, Gallagher M, Holland PC (2009) The basolateral amygdala is critical to the expression of pavlovian and instrumental outcome-specific reinforcer devaluation effects. J Neurosci 29:696-704.

Jones S, Sample CH, Hargrave SL, Davidson TL (2018) Associative mechanisms underlying the function of satiety cues in the control of energy intake and appetitive behavior. Physiol Behav 192:3749.

Kelley AE (2004) Ventral striatal control of appetitive motivation: role in ingestive behavior and reward-related learning. Neurosci Biobehav Rev 27:765-776.

Kelley AE, Bless EP, Swanson CJ (1996) Investigation of the effects of opiate antagonists infused into the nucleus accumbens on feeding and sucrose drinking in rats. J Pharmacol Exp Ther 278: 1499-1507.

Kelley AE, Baldo BA, Pratt WE (2005) A proposed hypothalamicthalamic-striatal axis for the integration of energy balance, arousal, and food reward. J Comp Neurol 493:72-85.

Kosheleff AR, Araki J, Tsan L, Chen G, Murphy NP, Maidment NT, Ostlund SB (2018) Junk food exposure disrupts selection of foodseeking actions in rats. Front Psychiatry 9:350.

Kourrich S, Calu DJ, Bonci A (2015) Intrinsic plasticity: an emerging player in addiction. Nat Rev Neurosci 16:173-184.

Koya E, Golden SA, Harvey BK, Guez-Barber DH, Berkow A, Simmons DE, Bossert JM, Nair SG, Uejima JL, Marin MT, Mitchell TB, Farquhar D, Ghosh SC, Mattson BJ, Hope BT (2009) Targeted disruption of cocaine-activated nucleus accumbens neurons prevents context-specific sensitization. Nat Neurosci 12:1069-1073.

Koya E, Cruz FC, Ator R, Golden SA, Hoffman AF, Lupica CR, Hope BT (2012) Silent synapses in selectively activated nucleus accumbens neurons following cocaine sensitization. Nat Neurosci 15: $1556-1562$.

Labno A, Warrier A, Wang S, Zhang X (2014) Local plasticity of dendritic excitability can be autonomous of synaptic plasticity and regulated by activity-based phosphorylation of Kv4.2. PLoS One 9:e8408.

Latagliata EC, Puglisi-Allegra S, Ventura R, Cabib S (2018) Norepinephrine in the medial pre-frontal cortex supports accumbens shell responses to a novel palatable food in food-restricted mice only. Front Behav Neurosci 12:7.

LeGates TA, Kvarta MD, Tooley JR, Francis TC, Lobo MK, Creed MC, Thompson SM (2018) Reward behaviour is regulated by the strength of hippocampus-nucleus accumbens synapses. Nature 564:258-262.

Moyer JR Jr, Thompson LT, Disterhoft JF (1996) Trace eyeblink conditioning increases CA1 excitability in a transient and learningspecific manner. J Neurosci16:5536-5546.

Mozzachiodi R, Byrne JH (2010) More than synaptic plasticity: role of nonsynaptic plasticity in learning and memory. Trends Neurosci 33:17-26.

Natsubori A, Tsutsui-Kimura I, Nishida H, Bouchekioua Y, Sekiya $H$, Uchigashima M, Watanabe M, de Kerchove d'Exaerde A, Mimura M, Takata N, Tanaka KF (2017) Ventrolateral striatal medium spiny neurons positively regulate food-incentive, goal-directed behavior independently of $D_{1}$ and $D_{2}$ selectivity. J Neurosci 37:2723-2733.

Nicola SM, Surmeier J, Malenka RC (2000) Dopaminergic modulation of neuronal excitability in the striatum and nucleus accumbens. Annu Rev Neurosci 23:185-215.

Oginsky MF, Goforth PB, Nobile CW, Lopez-Santiago LF, Ferrario CR (2016) Eating "junk-food" produces rapid and long-lasting increases in NAc CP-AMPA receptors: implications for enhanced cue-induced motivation and food addiction. Neuropsychopharmacology 41:2977-2986.

Ouyang J, Carcea I, Schiavo JK, Jones KT, Rabinowitsch A, Kolaric R, Cabeza de Vaca S, Froemke RC, Carr KD (2017) Food restriction induces synaptic incorporation of calcium-permeable AMPA receptors in nucleus accumbens. Eur $\mathrm{J}$ Neurosci 45:826-836.

Paxinos G, Franklin KBJ (2012) Paxinos and Franklin's the mouse brain in stereotaxic coordinates. São Paulo: Academic.

Pennartz CMA, Groenewegen HJ, Lopes da Silva FH (1994) The nucleus accumbens as a complex of functionally distinct neuronal ensembles: an integration of behavioural, electrophysiological and anatomical data. Prog Neurobiol 42:719-761.

Petrovich GD (2013) Forebrain networks and the control of feeding by environmental learned cues. Physiol Behav 121:10-18.

Roitman MF, Wheeler RA, Wightman RM, Carelli RM (2008) Realtime chemical responses in the nucleus accumbens differentiate rewarding and aversive stimuli. Nat Neurosci 11:1376-1377.

Rosenkranz JA, Grace AA (2002) Dopamine-mediated modulation of odour-evoked amygdala potentials during pavlovian conditioning. Nature 417:282-287.

Sheng M, Greenberg ME (1990) The regulation and function of c-fos and other immediate early genes in the nervous system. Neuron $4: 477-485$ 
Shiflett MW, Balleine BW (2010) At the limbic-motor interface: disconnection of basolateral amygdala from nucleus accumbens core and shell reveals dissociable components of incentive motivation. Eur J Neurosci 32:1735-1743.

Singer BF, Bubula N, Li D, Przybycien-Szymanska MM, Bindokas VP, Vezina P (2016) Drug-paired contextual stimuli increase dendritic spine dynamics in select nucleus accumbens neurons. Neuropsychopharmacology 41:2178-2187.

Smith RJ, Lobo MK, Spencer S, Kalivas PW (2013) Cocaine-induced adaptations in D1 and D2 accumbens projection neurons (a dichotomy not necessarily synonymous with direct and indirect pathways). Curr Opin Neurobiol 23:546-552.

Stefanelli T, Bertollini C, Lüscher C, Muller D, Mendez P (2016) Hippocampal somatostatin interneurons control the size of neuronal memory ensembles. Neuron 89:1074-1085.

Strickland JA, Austen JM, Sanderson DJ (2018) A biphasic reduction in a measure of palatability following sucrose consumption in mice. Physiol Behav 184:129-134.

Struthers WM, DuPriest A, Runyan J (2005) Habituation reduces novelty-induced FOS expression in the striatum and cingulate cortex. Exp Brain Res 167:136-140.

Stuber GD, Klanker M, De Ridder B, Bowers MS, Joosten RN, Feenstra MG, Bonci A (2008) Reward-predictive cues enhance excitatory synaptic strength onto midbrain dopamine neurons. Science 321:1690-1692.

Suto N, Laque A, De Ness GL, Wagner GE, Watry D, Kerr T, Koya E, Mayford MR, Hope BT, Weiss F (2016) Distinct memory engrams in the infralimbic cortex of rats control opposing environmental actions on a learned behavior. Elife 5:e21920.

Taha SA (2005) Encoding of palatability and appetitive behaviors by distinct neuronal populations in the nucleus accumbens. J Neurosci 25:1193-1202.

Taverna S, Canciani B, Pennartz CMA (2005) Dopamine D1receptors modulate lateral inhibition between principal cells of the nucleus accumbens. J Neurophysiol 93:1816-1819.

Te Morenga L, Mallard S, Mann J (2012) Dietary sugars and body weight: systematic review and meta-analyses of randomised controlled trials and cohort studies. BMJ 346:e7492.

Thompson DA, Moskowitz HR, Campbell RG (1976) Effects of body weight and food intake on pleasantness ratings for a sweet stimulus. J Appl Physiol 41:77-83.

Ting JT, Lee BR, Chong P, Soler-Llavina G, Cobbs C, Koch C, Zeng $H$, Lein E (2018) Preparation of acute brain slices using an opti- mized N-methyl-D-glucamine protective recovery method. $\mathrm{J}$ Vis Exp. Advance online publication. Retrieved February 26, 2018. doi: $10.3791 / 53825$.

Tonegawa S, Liu X, Ramirez S, Redondo R (2015) Memory engram cells have come of age. Neuron 87:918-931.

Tseng KY, O’Donnell P (2004) Dopamine-glutamate interactions controlling prefrontal cortical pyramidal cell excitability involve multiple signaling mechanisms. J Neurosci 24:5131-5139.

Warren BL, Mendoza MP, Cruz FC, Leao RM, Caprioli D, Rubio FJ, Whitaker LR, McPherson KB, Bossert JM, Shaham Y, Hope BT (2016) Distinct Fos-expressing neuronal ensembles in the ventromedial prefrontal cortex mediate food reward and extinction memories. J Neurosci 36:6691-6703.

West EA, Carelli RM (2016) Nucleus accumbens core and shell differentially encode reward-associated cues after reinforcer devaluation. J Neurosci 36:1128-1139.

Whitaker LR, Hope BT (2018) Chasing the addicted engram: identifying functional alterations in Fos-expressing neuronal ensembles that mediate drug-related learned behavior. Learn Mem 25:455460.

Whitaker LR, Carneiro de Oliveira PE, McPherson KB, Fallon RV, Planeta CS, Bonci A, Hope BT (2016) Associative learning drives the formation of silent synapses in neuronal ensembles of the nucleus accumbens. Biol Psychiatry 80:246-256.

Whitaker LR, Warren BL, Venniro M, Harte TC, McPherson KB, Bossert JM, Shaham Y, Bonci A, Hope BT (2017) Bidirectional modulation of intrinsic excitability in rat prelimbic cortex neuronal ensembles and non-ensembles following operant learning. J Neurosci 37:8845-8856.

Wilson CJ (2007) GABAergic inhibition in the neostriatum. Prog Brain Res 160:91-110.

Yang H, de Jong JW, Tak YE, Peck J, Bateup HS, Lammel S (2018) Nucleus accumbens subnuclei regulate motivated behavior via direct inhibition and disinhibition of VTA dopamine subpopulations. Neuron 97:434-449.e4.

Ziminski JJ, Hessler S, Margetts-Smith G, Sieburg MC, Crombag HS, Koya E (2017) Changes in appetitive associative strength modulates nucleus accumbens, but not orbitofrontal cortex neuronal ensemble excitability. J Neurosci 37:3160-3170.

Ziminski JJ, Sieburg MC, Margetts-Smith G, Crombag HS, Koya E (2018) Regional differences in striatal neuronal ensemble excitability following cocaine and extinction memory retrieval in Fos-GFP mice. Neuropsychopharmacology 43:718-727. 